\title{
CARACTERIzAÇÃo E AVALIAÇÃo dE FRUTOS dE TANGORES E TANGELOS
}

\author{
JOÃO PEDRO DELGADO \\ Engenheiro Agrônomo
}

ORIENTADOR: Prof. Dr. SALIM SIMÃO

Dissertação apresentada à Escola Superior de Agricultura "Luiz de Queiroz", da Universidade de São Paulo, para obtenção do título de Mestre em Agronomia, Área de Concentração Fitotecnia.

\author{
PIRACICABA \\ ESTADO DE SÃO PAULO - BRASIL \\ JANEIRO - 1999
}


Dados Internacionais de Catalogação na Publicação (CIP) DIVISÃO DE BIBLIOTECA E DOCUMENTAÇÃO - Campus "Luiz de Queiroz"/USP

Delgado, Joāo Pedro

Caracterização e avaliação de frutos de tangores e tangelos / Joảo Pedro Delgado. - Piracicaba, 1999.

$68 \mathrm{p.}$ : il.

Dissertação (mestrado) - - Escola Superior de Agricultura Luiz de Queiroz, 1999.

Bibliografia.

1. Fruta citrica 2. Tangelo 3. Tangerina Murcote 4. Seleção vegetal I. Titulo

CDD 634.31 
Para os meus pais

João e Zélia,

Minha Gratidão.

Para os meus irmãos, Rosaly, Maristela, Valdir e Cássio, Ofereço.

Para minha esposa Margarida e meus filhos, Natália, João Pedro e Douglas, Dedico. 


\section{AGRADECIMENTOS}

Expresso meus sinceros agradecimentos a todas as pessoas e instituições, que direta ou indiretamente, colaboraram para a realização do presente trabalho, especialmente:

- ao Dr. Salim Simão, Professor do Departamento de Produção Vegetal, da ESALQ/USP, pela orientação, ensinamentos e apoio;

- ao Dr. José Orlando de Figueiredo, Pesquisador Científico, do Centro de Citricultura Sylvio Moreira, pelas condiçōes proporcionadas durante o desenvolvimento do trabalho, pela orientação, amizade e apoio;

- à Dra. Rose Mary Pio, Pesquisadora Cientifica, do Centro de Citricultura Sylvio Moreira, pela colaboração e sugestões apresentadas;

- à MSc. Maria Izalina Ferreira Alves, Professora do Departamento de Ciências Exatas da ESALQ-USP, pela orientação estatística e na confecção de gráficos;

- ao Marcos A. Pozzan, Engenheiro Agrônomo, da MONTECITRUS TRADING, pelo fornecimento de resultado da análise do tangelo Orlando;

- ao Dr. Marco A.Galli Professor da disciplina de Fitopatologia da Faculdade de Agronomia "Manoel Carlos Gonçalves", pela adaptação dos diagramas de raio de sol (sun ray plots); 
- ao Dr. Gerd Walter Müller, Pesquisador-Consultor, do Centro de Citricultura Sylvio Moreira, pela revisão do Summary;

- à MSc.Maria Helena Calafiori, Professora Titular de Entomologia do Departamento de Fitotecnia da Faculdade de Agronomia "Manoel Carlos Gonçalves" pelo incentivo e amizade;

- à Dra. Nilva Terezinha Teixeira, Professora Titular de Nutrição Mineral do Departamento de Química, Solos e Tecnologia da Faculdade de Agronomia "Manoel Carlos Gonçalves" pelo estímulo e amizade;

- ao Dr. João Tessariolli Neto, Professor Titular do Departamento de Produção Vegetal, da ESALQ/USP, pelo incentivo na realização deste trabalho;

- aos Doutores Joaquim Teófilo Sobrinho e Jorgino Pompeu Júnior, Diretores do Centro de Citricultura Sylvio Moreira pelas facilidades na realização das análises de frutos;

- à Sra. Valéria Xavier Paula Garcia, Técnica do Laboratório, do Centro de Citricultura Sylvio Moreira, pela colaboração na realização das análises dos frutos; 
- aos funcionários e colegas do Departamento de Produção Vegetal, da ESALQ/USP, do Centro de Citricultura Sylvio Moreira e do Departamento de Fitotecnia da Faculdade de Agronomia "Manoel Carlos Gonçalves", que de alguma maneira colaboraram para a realização deste trabalho;

- à Faculdade de Agronomia "Manoel Carlos Gonçalves" - FUNDAÇÃO PINHALENSE DE ENSINO, pela oportunidade da realização do Curso de Pós - Graduação a nivel de Mestrado;

- ao Departamento de Produção Vegetal, da Escola Superior de Agricultura Luiz de Queiroz, pelos ensinamentos proporcionados e na realização do Curso de Pós-Graduação à nível de Mestrado;

- ao Conselho Nacional de Desenvolvimento Científico e Tecnológico(CNPq) e à Coordenação de Aperfeiçoamento de Pessoal de Nivel Superior (CAPES) pela concessão da bolsa de estudo. 


\section{SUMÁRIO}

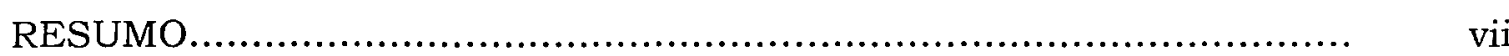

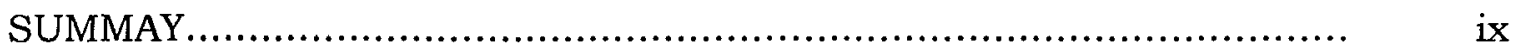

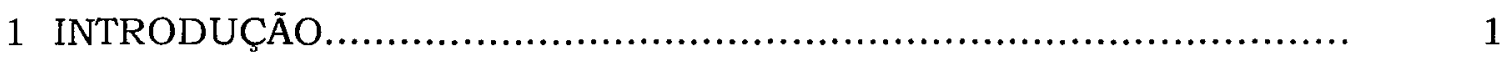

2 REVISÃO DE LITERATURA................................................... 3

3 MATERIAL E MÉTODOS...................................................... 10

3.1 Local da coleção.................................................................. 10

3.2 Variedades................................................................ 10

3.3 Coleta da amostra dos frutos........................................... 11

3.4 Caracteristicas externas dos frutos....................................... 11

3.4.1 Altura e Diâmetro......................................................... 11

3.4.2 Coloração.................................................................. 12

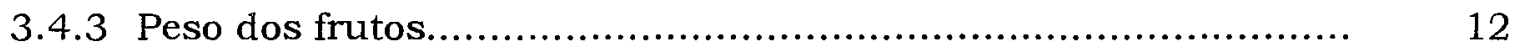

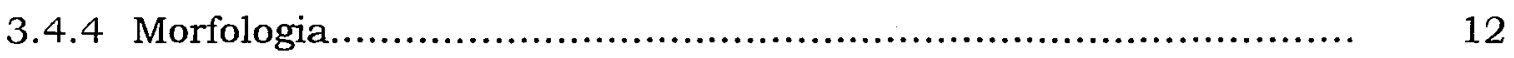

3.5. Caracteristicas internas do fruto.......................................... 12

3.5.1 Rendimento de suco.................................................... 12

3.5.2 Coloração do suco........................................................... 13

3.5.3 Sólidos solúveis............................................................. 13

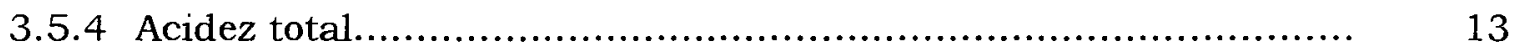

3.5.5 Relação sólidos solúveis: acidez (ratio).................................. 13

3.5.6 Índice tecnológico ( $\mathrm{kg}$ sólidos solúveis por caixa)...................... 13

3.5.7 Número de sementes.................................................... 14

3.6 Metodologia estatística...................................................... 14

4 RESULTADOS E DISCUSSÃO................................................. 18

4.1 Ficha pomológica das variedades....................................... 18

4.2 Caracteristicas externas dos frutos........................................ 25

4.2.1 Altura dos frutos........................................................ 25

4.2.2 Diâmetro dos frutos......................................................... 25

4.2.3 Altura/diâmetro dos frutos................................................ 25 
4.2.4 Peso dos frutos.................................................... 28

4.2.5 Coloração da casca............................................. 31

4.2.6 Morfologia............................................................ 31

4.3 Caracteristicas internas dos frutos .................................. 32

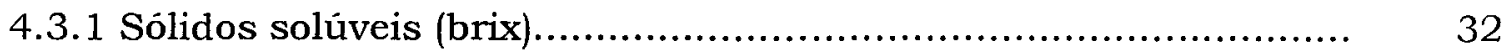

4.3.2 Acidez total........................................................ 34

4.3.3 Relação sólidos solúveis: acidez (ratio)............................. 35

4.3.4 Rendimento de suco.............................................. 36

4.3 .5 Índice tecnológico.................................................. 40

4.3.6 Número de sementes.......................................... 41

4.3.7 Coloração da polpa..................................................... 42

4.4 Gráficos de raios de sol.............................................. 44

4.4.1 Tangor da Índia....................................................... 50

4.4.2 Tangor Santa Maria Madalena.................................... 51

4.4 .3 Tangor Ortanique................................................. 51

4.4.4 Tangelo Seminole.................................................... 52

4.4.5 Tangelo Sampson................................................... 53

4.4.6 Tangelo Minneola................................................ 54

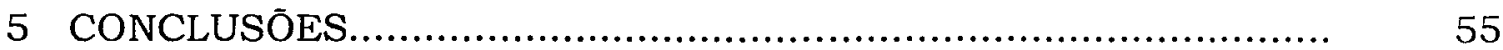

REFERENCIAS BIBLIOGRÄFICAS........................................ 56

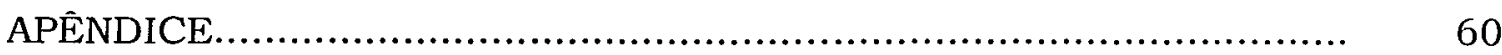




\title{
CARACTERIZAÇÃO E AVALIAÇÃO DE FRUTOS DE TANGORES E TANGELOS
}

\author{
Autor : JOÃO PEDRO DELGADO \\ Orientador: PROF.DR. SALIM SIMÃO
}

\section{RESUMO}

Com a finalidade de iniciar os estudos de três tipos de tangores e três tipos de tangelos, com possivel valor para a utilização comercial, foram analizadas as caracteristicas de seus frutos, nas condiçōes climáticas do Centro de Citricultura Sylvio Moreira (CCSM), em Corderópolis, SP, pertencente ao Instituto Agronômico de Campinas (IAC). As variedades estudadas, de origem nucelar foram as seguintes: tangores da Índia, Santa Maria Madalena e Ortanique e tangelos Minneola, Sampson, Seminole, selecionadas dentre as existentes no Banco Ativo de germoplasma de Citros, do CCSM. As plantas estavam enxertadas em tangerina 'Cleopatra' Citrus reshni Hort. ex Tan. e contavam com dez anos de plantio, no inicio do estudo. O estudo desenvolveu-se durante dois anos consecutivos, ou seja, no ano de 1996, entre os meses de julho a setembro e em 1997, entre os meses de junho a setembro, com análises realizadas aproximadamente de quinze em quinze dias. Foram estudadas as seguintes caracteristicas do frụto: altura, diâmetro, altura/diâmetro, peso, coloração da casca, morfologia, sólidos solúveis (brix), acidez, relação sólidos solúveis: acidez (ratio), rendimento de suco, indice tecnológico, número de sementes e coloração da polpa. Este trabalho possibilitou a descriçāo das características do fruto de cada tipo. Os resultados obtidos com os frutos permitiram as seguintes conclusões: As 
variedades que apresentaram maiores valores médios em tamanho de fruto foram os tangelos Sampson, Seminnole e o Minneola. Os maiores valores médios para peso dos frutos foram obtidos com os tangelos Minneola e Sampson. A maioria das variedades apresentaram alto rendimento de suco, acima de 50\%, ficando os maiores valores para os tangelos Minneola, Sampson e Seminole e para o tangor Ortanique. Todas as variedades apresentaram alto indice de sementes por fruto. Os tangores e tangelos estudados, de uma maneira geral, não apresentaram resultados promissores para serem utilizados como copa, no periodo estudado. 


\title{
CHARACTRIZATION AND EVALUATION OF TANGORS AND TANGELOS FRUITS
}

\author{
Author : JOĀO PEDRO DELGADO \\ Adviser: PROF.DR. SALIM SIMÃO
}

\section{SUMMARY}

Three types of tangors and three of tangelos, with potential commercial value, were analysed in regard to their fruit characteristics, under the climatic conditions of the Centro of Citriculture Sylvio Moreira (CCSM) - Instituto Agronômico, Campinas, (IAC) located in Cordeirópolis country, São Paulo State, Brazil. The analysed types (materials) from nucellar origin, were: India, Santa Maria Madalena and Ortanique tangors and Minneola, Sampson and Seminole tangelos, selected among those existing in the active germoplasm bank of the CCSM. The plants were grafted on 'Cleopatra' mandarine and were 10 years old at the beginning of the evaluation. The study was carried out during two years in a row, starting from July through September 1996 and from June through September 1997, being the analyses carried out approximately, bi-monthly. Studied, were the following characteristics of the fruits: height, diameter, height/diameter, weight, rind colour, morphology, soluble solids (brix), acidity, soluble solids relation: acidity (ratio), juice yield, technological index, seed number and pulp colour. This work made the description of the fruit's characteristics from each type, possible. From the results obtained, the following conclusions could be drawn: The varieties that presented the highest medium values in fruit's size were the Sampson, Seminole and the Minneola tangelos. The highest medium values for fruti's weight were obtained with the Minneola and Sampson tangelo. Most of the 
varieties presented high juice's yield, above $50 \%$, being the highest values of Minneola, Sampson, Seminole tangelos and for the Ortanique tangor. All the varieties presented high rate of seeds per fruit. The tangores and tangelos studied, in a general way, were not suitable to be used as canopies in the period in which they studied. 


\section{INTRODUÇÃO}

No Estado de São Paulo, as principais variedades citricas utilizadas como copas são as laranjas, estando as tangerinas em segundo lugar. Com bastante expressão entre as tangerinas encontra-se o hibrido denominado tangor 'Murcott' (Citrus reticulata Blanco $\mathrm{x}$ Citrus sinensis (L.) Osbeck) que participa com $35 \%$ de número de plantas dentro do grupo das tangerinas (Figueiredo, 1991).

A citricultura paulista atualmente está implantada em sua grande maioria sobre o porta enxerto limão 'Cravo' (Citrus limonia Osbeck), o que a torna vulnerável ao aparecimento de diversos problemas, principalmente os relacionados com doenças. Com a constatação do Declínio dos Citros em pomares comerciais, foram iniciados novos experimentos utilizando outros porta-enxertos e entre eles estava o tangelo Orlando (Citrus reticulata Blanco $\mathrm{x}$ Citrus paradisi Macf.), pois è sabido que existem porta-enxertos tolerantes e que a doença de alguma forma, se relaciona com o porta-enxerto utilizado. Em experimentos realizados pelos técnicos do Centro de Citricultura Sylvio Moreira (CCSM), pertencente ao Instituto Agronômico de Campinas e situado no municipio de Corderópolis, SP, os dados mostraram que esse hibrido apresentou produções semelhantes às do limão 'Cravo' quando enxertado com as laranjas 'Barão', Hamlin' e 'Valência' em solos argilosos e em solos arenosos. Ele vem mostrando ser tolerante ao Declínio (Pompeu Júnior, 1991).

No mundo todo o grupo das tangerinas é bastante importante em relação ao plantio comercial, vindo após o da laranja. No Brasil esse interesse vem crescendo tanto para as variedades de mesa como para a industrialização. Esse fato deve-se aos baixos preços pagos pelos industriais por uma caixa de 
laranja e ao problema sério e gravissimo que afeta atualmente a citricultura paulista, a Clorose Variegada dos Citros ou CVC.

A pequena diversidade desse grupo, reunida em apenas quatro variedades comerciais, a saber: tangerinas 'Ponkan', 'Cravo' e Mexerica 'do Rio' e o tangor 'Murcott', tem incentivado pesquisadores e citricultores na busca de outras variedades que possuam caracteristicas de maturação fora de época, e que apresentem qualidades adequadas ao paladar do brasileiro e também ao do consumidor estrangeiro, visando a exportação de frutos in natura.

A Estação Experimental de Limeira, hoje Centro de Citricultura, desde sua instalação em 1928, vem reunindo em coleção, valioso material genético originário de diversas regiōes do Brasil e do exterior. Atualmente a mesma tem aproximadamente 2000 acessos. Desses, 19\% são constituídos por tangerinas e seus hibridos.

A difícil conservação desse Banco de Germoplasma terá melhor sentido se o material for estudado e devidamente avaliado quanto ao seu potencial de uso como copas, porta-enxertos, indicadores de viroses e para a produção de híbridos.

Até o presente, apenas alguns cultivares tem sido utilizados como copas ou porta-enxertos, acentuando, como já mencionado, a vulnerabilidade da cultura de citros a graves problemas já ocorridos ou em potencial.

Atualmente o tangor 'Murcott' pelas suas qualidades é bem aceito no mercado nacional e internacional como fruta fresca. Já o tangelo Orlando é mais uma opção para a diversificação de porta-enxertos, pois é tolerante ao Declínio dos Citros. Acredita-se ainda que no futuro, esse híbrido também possa ser utilizado para a fabricação de suco concentrado congelado. Atualmente estão sendo desenvolvidos testes com essa finalidade, pelo grupo constituinte da Montecitrus Trading S/A, situada no municipio de Monte Azul Paulista, SP.

A seleção de novos tangores e tangelos que possam ter valor para utilização comercial, quer como copas, quer como porta-enxertos, torna-se pois de grande valia. Este trabalho objetivou a seleção dos materiais em estudo, para utilização principalmente como copas. 


\section{REVISÃO DE LITERATURA}

Giacometti (1977) expõe bem o fato conhecido de que a situação da citricultura brasileira é extremamente vulnerável, pois, está praticamente apoiada num único porta-enxerto - o limão 'Cravo'. Também, o fato de serem explorados poucos cultivares, cujos frutos serão consumidos ao natural ou para a industrialização, acentua essa vulnerabilidade.

Os frutos das variedades de citros que vão ser consumidos ao natural, precisam preencher certos requisitos de qualidade, tais como: aspecto externo e interno; coloração da casca e do suco; tamanho apropriado para a comercialização; casca fina; gomos de paredes delicadas; época de maturação adequada; suco com adequado equilíbrio entre o teor de sólidos solúveis e acidez; aroma agradável; alto teor de vitamina C; brix, acidez e ratio adequados para consumo in natura e industrialização; pequeno número de sementes; resistência ao transporte e boa conservação. Os dois últimos itens são bastante importantes quando para a exportação de fruta fresca (Salibe, 1974).

A maioria das variedades citricas que alcançaram grande aceitação e são cultivadas em grande escala, preenchem essas exigências, tais como as laranjas 'Pêra', 'Natal' e 'Valência'.

Cada variedade citrica produz frutos com caracteristicas próprias. Entretanto, a qualidade varia em função de muitos fatores, como clima, solo, porta-enxerto, adubação, tratos culturais, pulverizações fitossanitárias, entre outros. Dentro de uma mesma planta, a composição do fruto varia. As laranjas que recebem maior insolação são mais doces e mais ricos em vitamina $\mathrm{C}$, que as mais sombreadas. Frutos pequenos em geral são mais ácidos, mais rico em vitamina $\mathrm{C}$ e com maior teor de açúcares, que os de maior tamanho. Mesmo 
dentro de uma mesma laranja a qualidade varia, sendo que a porção estilar apresenta normalmente suco mais rico em açúcares (Salibe,1974).

Quando os frutos são destinados a industrializaçāo, certas caracteristicas importantes devem ser observadas. Os frutos necessitam ter dimensões adequadas, nāo devem apresentar ferimentos na casca, nāo devem estar excessivamente atacados por ácaros ou sujos e o estágio de maturação necessita estar no ponto ideal. O controle do grau de maturação é feito pela relação sólidos solúveis: acidez (ratio) (Viégas, 1991).

O teor de sölidos solúveis, expresso em $\mathrm{kg} /$ caixa de 40,8 $\mathrm{kg}$ de frutos, é um parâmetro que vem adquirindo muita importância, principalmente quando a variedade se presta para a industrialização. Essa tendência para se comercializar a laranja com base no teor de sólidos solúveis, como é realizado nos Estados Unidos, forçará a melhoria da qualidade da fruta e premiará os melhores produtos (Viégas, 1991).

Para receber as frutas, as indústrias de suco de laranja exigem uma relação minima entre a proporção de ácidos e a de sólidos solúveis. Essa relação exigida varia entre $1: 11,5$ a $1: 18,0$. Para exportação permite-se a colheita e a remessa de frutos para a Europa, com relação minima de 1:6,5. Para o paladar do brasileiro as laranjas devem apresentar relação acidez: sólidos solúveis acima de 1:8,0. A colheita das laranjas somente deverá ser iniciada quando for atingido esse minimo e a fruta apresentar mais de $40 \%$ de suco (Salibe, 1974).

Segundo Figueiredo (1991), as principais variedades de tangerinas, mexericas e hibridos plantados no Estado de São Paulo são: 'Cravo', 'Ponkan', Mexerica 'do Rio' e tangor 'Murcott'. O mesmo autor menciona como caracteristicas agronômicas do fruto dessas variedades as seguintes:

- Tangerina 'Cravo' Citrus reticulata Blanco: “Os frutos tem a forma achatada, com cerca de 20 a 22 sementes e pesam em média 135 g, a casca é de cor alaranjada forte, com espessura média e vesículas de óleo salientes. A polpa é de cor alaranjada bem forte, apresentando textura frouxa. Tem suco abundante, $48 \%$ do peso do fruto, com teores médios de Brix - 10,8\%, 
Acidez 0,8\% e 'Ratio' de 13,5. É cultivar que apresenta frutos de maturação precoce, podendo se estender de março a maio".

- Tangerina Mexerica Citrus deliciosa Tenore: “Os frutos da mexerica 'do-Rio' têm a forma achatada, com aproximadamente 30 sementes e pesam em média $130 \mathrm{~g}$; a casca é de cor amarelo alaranjado, com espessura fina e vesículas de óleo em nivel. A polpa è de cor alaranjada e apresenta textura frouxa. Tem $40 \%$ do peso do fruto em suco, com teores médios de Brix 10,4\%, Acidez - 0,99\% e 'Ratio' de 10,5. Seus frutos amadurecem de abril a junho, alcançando ótimos preços no mercado, sendo considerada variedade de meia-estação".

- Tangerina 'Ponkan' Citrus reticulata Blanco: "Seus frutos são de forma achatada com 5 a 8 sementes e de peso médio de $138 \mathrm{~g}$; sua casca é de cor alaranjada forte, de espessura média e vesiculas de óleo salientes. Tem polpa de cor alaranjada e textura frouxa. O suco corresponde a $43 \%$ do peso do fruto, com teores médios de Brix - 10,8\%, Acidez - 0,85\% e 'Ratio' de 12,7. O cultivar apresenta maturação dos frutos de meia-estação, de maio a julho".

Tangor 'Murcott' Citrus reticulata Blanco x Citrus sinensis Osbeck: "Os frutos tem a forma achatada, com aproximadamente 20 sementes e pesam em média 140 g; a casca é de cor laranja vivo com espessura fina, aderente e vesiculas de óleo em nivel. A polpa é de cor laranja vivo e apresenta textura firme. Seu suco é abundante, $48 \%$ do peso do fruto, com teores médios de Brix $-12,6 \%$, Acidez - 0,92\% e ratio de 13,7. E cultivar que apresenta frutos de maturação tardia, podendo se estender de meados de.julho a meados de outubro".

As tangerinas e seus hibridos apresentam, geralmente, boa resistência ao frio quando comparadas com outras espécies ou variedades citricas cultivadas comercialmente. Faz exceçāo o tangor Temple, que é menos 
resistente que as laranjeiras. Entretanto, seus frutos sofrem maior dano com as geadas do que a maioria dos frutos das laranjeiras e pomeleiros (Saunt, 1992).

Elas tem facilidade em adaptar-se a diferentes tipos de clima, como o subtropical e também em regiōes desérticas. As variedades de tangerinas são muito especificas em exigências climáticas para a obtenção de boa produção e qualidade dos frutos. Como exemplo, podem ser mencionadas 'Ponkan', Tankan, Ellendale e Dancy, que são mais apropriadas às condições de clima subtropical. Raramente elas se desenvolvem nas mesmas condições que a tangerina Satsuma. Esta é mais produtiva e adquire excelente qualidade somente em regiōes que tenham invernos bem frios. Cabe ressaltar que, de todas as tangerinas, a Satsuma è a mais resistente ao frio, sobretudo se enxertada sobre Poncirus trifoliata.

Dentre as tangerinas, no que se refere a requisitos de clima, a Clementina apresenta distribuição geográfica restrita, limitada às áreas litorāneas do Marrocos, Espanha e Córsega.

Muitas tangerinas e híbridos, em particular a Mexerica e a Dancy, assim como seus híbridos, tendem a apresentar alternância de produção, de maneira que colheitas abundantes de frutos pequenos são seguidas por colheitas de frutos grandes de pior qualidade. Às vezes, recomendam-se outras variedades que atuam como polinizadoras para ser conseguida uma melhor qualidade do fruto. Entretanto, várias práticas culturais como anelamento de ramos, pulverizações com reguladores de crescimento e raleio manual são utilizados para corrigir esse comportamento irregular (Saunt, 1992).

Via de regra, a maioria dos cultivares de citros requer o desenvolvimento de semente para uma frutificação adequada. A polinização é grandemente auxiliada pelos insetos, especialmente pelas abelhas, uma vez que o pólen dos citros apresenta maior peso e é comprido; dessa forma nāo é levado pelo vento. Em geral, não há necessidade de polinização cruzada e o plantio de uma única variedade pode produzir rendimentos satisfatórios (Guardiola, 1992).

A auto incompatibilidade é razoavelmente freqüente em alguns tipos de tangerinas e hibridos, tais como Orlando, Minneola, Nova e Osceola, 
entre outros. Quando essas variedades são autopolinizadas, o tubo polínico cresce lentamente devido à presença de inibidores no estilete, embora seu pólen seja freqüentemente viável e efetivo em outras variedades. Na ausência de partenocarpia, seja natural ou induzida, a frutificação depende da polinização cruzada com uma variedade compativel (Guardiola, 1992).

Embora sejam recomendados plantios mistos para assegurar uma frutificação adequada, o número excessivo de sementes é indesejável para frutos com valor comercial, principalmente para mesa.

Chitarra (1981) analisou quinzenalmente, de março a junho, os frutos da tangerina 'Ponkan', cultivada em Lavras (MG) e Perdões (MG) e, de maio a outubro, o tangor 'Murcott' cultivado em Alfenas (MG). Os resultados demonstraram apresentar a Ponkan', boas caracteristicas para o consumo in natura, a partir da primeira quinzena de abril, quando cultivada em Lavras e primeira quinzena de maio, quando plantada em Perdōes. A 'Murcott' pode ser utilizada tanto para consumo ao natural como para industrialização, tendo no último caso, como fator negativo, o elevado número de sementes por fruto, em torno de 20. A época indicada para o início da colheita para esse cultivar é a segunda quinzena de julho, na regiāo de Lavras.

Genú et al. (1981) conduzindo um experimento para conhecer as caracteristicas da laranja 'Pêra' cultivada nos cerrados do Distrito Federal, estabeleceram curvas de maturação a fim de indicar a provável época ideal para a colheita dos frutos. Concluiram que o tamanho e o peso dos frutos apresentam-se com valores abaixo dos padrōes normais da variedade, apesar de terem rendimento de suco superior a $40 \%$. Os frutos foram considerados ideais para o consumo in natura a partir de maio, enquanto que para a industrialização devem ser colhidos a partir de junho com ratio atingindo 11,9 e $45,55 \%$ de rendimento em suco.

A mistura de sucos é uma prática constante e comum na industrialização dos citros. Esse processo visa melhorar a coloração dos sucos citricos recorrendo às variedades mais coloridas. A utilização de suco de algumas variedades de tangerinas auxilia bastante nesse processo (Pio, 1992). 
Alguns hibridos de tangerinas tem se mostrado com bom potencial em paises como Espanha, Israel, Estados Unidos, Austrália e Japão. Pode ser citado como exemplo, na Austrália, os plantios de tangor 'Murcott', em regiões onde as Clementinas não se adaptam bem. No Japão, o plantio de 'Murcott' tem tido muito êxito quando efetuado em estufas apresentando frutos com maturação tardia (abril e maio), excelente coloração laranja avermelhada e sem lesões. Outro exemplo, é o crescente plantio de tangelo 'Nova' em áreas de cultivos da Espanha e de Israel, onde recebeu as denominações de Clemenville e Suntina, respectivamente. Na Flórida, esse tangelo vem ganhando popularidade em detrimento do tangelo Orlando (Saunt, 1992).

Segundo Pompeu Jünior (1991), o limão 'Cravo', é praticamente o único porta-enxerto sobre o qual foi construida a citricultura brasileira. A principal inconveniência da utilização de um único porta-enxerto já foi demonstrada pela virose Tristeza que, na década de 40, destruiu quase toda a citricultura brasileira entāo apoiada sobre o porta-enxerto laranja 'Azeda'. Mais recentemente, uma nova doença, o Declinio dos Citros, constatada na década de 70 , vem causando a morte de milhões de plantas enxertadas sobre limão 'Cravo'.

De acordo com Tubélis (1994), o Fundo Paulista de Defesa da Citricultura ( FUNDECITRUS), realizou levantamentos sobre a ocorrência da CVC em propriedades citricolas do Estado de São Paulo, na faixa nobre da citricultura que vai de Limeira até o municipio de São José do Rio Preto, uma extensão continua de citros. Foi constatado que das 3.494 propriedades vistoriadas, $83 \%$ contavam com a presença da CVC nas variedades de laranjas, e que não existia a presença da CVC nas tangerinas e seus híbridos.

A pesquisa e a experimentação vêm mostrando que a utilização de outros porta-enxertos, como as tangerinas 'Cleopratra' e 'Sunki' e o trifoliata, permitem obter frutos de melhor qualidade e maturação mais precoce ou mais tardia, que podem resultar em beneficios financeiros ao produtor. Outros portaenxertos selecionados nos diversos experimentos foram: limāo 'Volkameriano'; tangerinas Oneco, Batangas e Swatow; tangelo Orlando e as laranjas doces DAC, 'Hamlin', A, e Orvalho de Mel (Pompeu Júnior, 1991). 
Segundo Silva et al.(1990), o tangelo Orlando é tolerante ao Declínio dos Citros e a partir de 1988 participou da diversificação do limão 'Cravo', com pequeno número de plantas, por não existirem sementes disponiveis na época.

Nos Estados Unidos, segundo Hodgson (1967), o tangelo Orlando é caracterizado como fruta de tamanho médio a grande, forma oblata a subglobosa sem pescoço, com sementes, casca fina e de cor alaranjada, textura firme, com 12 a 14 segmentos, de polpa alaranjada com bastante suco. sabor suavemente doce. Tem boa resistência ao transporte, e é de sabor agradável e popular na Flórida.

Centenas de outras variedades necessitam ser estudadas, verificadas as suas qualidades e as expectativas para a utilização, de modo a contribuir na solução de diversos problemas relacionados à produtividade agricola.

Existem poucos trabalhos na literatura disponivel, sobre os materiais aqui propostos para estudo. 


\section{MATERIAL E MÉTODOS}

Foram estudadas três variedades de tangores e três variedades de tangelos, todas de clone nucelar e selecionadas no Banco Ativo de Germoplasma de Citros (BAG-Citros), do Instituto Agronômico de Campinas, situado no Centro de Citricultura Sylvio Moreira. Essas plantas encontram-se enxertadas em tangerina 'Cleópatra' - Citrus reshni Hort. ex Tan. e contavam com 10 anos de plantio no inicio do estudo.

\subsection{Local da coleção}

O Centro de Citricultura apresenta as seguintes coordenadas geográficas: $22^{\circ} 32^{\prime}$ de latitude sul e $4^{\circ} 27^{\prime}$ de longitude, altitude de $639 \mathrm{~m}$, clima do tipo Cwa, segundo a classificação de Köppen. O solo é do tipo Latossolo Vermelho-Escuro-orto. A média de precipitaçāo pluviométrica anual é de $1.375,3 \mathrm{~mm}$. A média anual de umidade relativa do ar é de $74,2 \%$. A temperatura média anual é de $20,2^{\circ} \mathrm{C}$, sendo a média das máximas igual a $27,5^{\circ} \mathrm{C}$ e a média das minimas igual a $14,5^{\circ} \mathrm{C}$ (Tabela 15 ).

\subsection{Variedades}

Tangores * $\quad$ 249 - Tangor da Índia

603 - Tangor Santa Maria Madalena

554 - Tangor Ortanique

* número correspondente a variedade no BAG-Citros. 
Tangelos * 235 - Tangelo Minneola

237 - Tangelo Sampson

239 - Tangelo Seminole

\subsection{Coleta da amostra dos frutos}

Para a coleta dos frutos que formaram as amostras foram utilizadas as três plantas de cada tangor e as três plantas de cada tangelo, que compõem o BAG-Citros, sendo coletados cinco frutos por árvore num total de 15 por variedade. Tais frutos foram colhidos na porção externa da copa, na faixa compreendida entre $1,0 \mathrm{~m}$ e $2,0 \mathrm{~m}$ de altura do solo e em toda a extensão do perimetro da planta

As amostras foram coletadas nos anos de 1996 e de 1997. Iniciadas as colheitas, elas se repetiram de 15 em 15 dias aproximadamente (Tabelas 5 a 14).

\subsection{Caracteristicas externas dos frutos}

\subsubsection{Altura e diâmetro}

As determinações de altura e diâmetro dos frutos foram feitas por leitura direta em cada fruto da amostra, com o auxilio de escala graduada em centimetros. A partir desses valores, foi calculada a relação entre a altura e o diâmetro (H/D), dividindo-se a altura do fruto pelo seu diâmetro.

\footnotetext{
* número correspondente a variedade no BAG-Citros.
} 


\subsubsection{Coloraçāo}

A avaliação da coloração da casca foi baseada no Atlas de Cores denominado Pflanzenfarben Atlas (Biesalski, 1957).

\subsubsection{Peso dos frutos}

O peso total dos frutos de cada amostra foi obtido, de uma só vez, através de uma balança, marca Filizola, com capacidade de até $15 \mathrm{~kg}$ e sensibilidade de 5 gramas.

\subsubsection{Morfologia}

As caracteristicas morfológicas (forma do fruto, ápice e base) foram baseadas no Descriptors for Citrus (IBPGR, 1988).

\subsection{Caracteristicas internas do fruto}

\subsubsection{Rendimento de suco}

Foi determinado após esmagamento do fruto na extratora $\mathrm{OIC}^{1}$ comprimento $=265 \mathrm{~mm}$; furos de diâmetro $=0,6 \mathrm{~mm}$; área de vazão $=20 \%$ e calculado através da relação peso do suco / peso do fruto e expresso em porcentagem.

\footnotetext{
${ }^{1}$ Organização Internacional Centenário - fabricante da extratora OIC, modelo OTTO 1.800. Limeira, SP
} 


\subsubsection{Coloraçāo do suco}

A coloração do suco foi avaliada também, segundo o Atlas de Cores Pflanzenfarben Atlas (Biesalski, 1957).

\subsubsection{Sólidos solúveis}

$\mathrm{O}$ teor de sólidos solúveis foi determinado por leitura direta no refratômetro B \& S, modelo RFM 330. Os dados foram corrigidos pela temperatura e pela acidez do suco.

\subsubsection{Acidez total}

A acidez foi obtida por titulação de $25 \mathrm{ml}$ de suco, com uma solução de hidróxido de sódio de normalidade de 0,3125 e usando-se fenolftaleina como indicadora.

\subsubsection{Relação sólidos solúveis: acidez (ratio)}

Foi calculada a relação sólidos solüveis: acidez considerando-se o valor da acidez igual a 1. Essa relação indica o estado de maturação dos frutos citricos.

\subsection{6 Índice tecnológico ( $\mathbf{k g}$ sólidos solúveis por caixa)}

Este indice (Di Giorgi et al., 1990) foi obtido pela equação: 
IT $=\frac{\text { rendimento em suco } x \text { sólidos solúveis } \times 40,8}{10.000}$

onde:

IT = Índice Tecnológico

Rendimento em suco = relação peso do suco e peso do fruto.

Sôlidos solúveis $=$ teor de sólidos solúveis

40,8 = peso padrão da caixa de colheita de laranja $(\mathrm{em} \mathrm{kg})$

\subsubsection{Número de sementes}

Foi contado o número de sementes de cinco frutos, no ano de 1996 e 1997.

\subsection{Metodologia estatistica}

Foi adotado para todas as variáveis, e dentro de cada variedade, o seguinte modelo estatistico:

Média aritmética amostral:

$$
\bar{x}=\sum_{i=1}^{n} \frac{x_{i}}{n}
$$


onde $x_{i}$ representa a i-ésima observação da amostra considerada e $\mathrm{n}$ é o número total de observações.

Variância amostral: É um modelo que mede a variação das observações em torno da média. $\dot{\mathrm{E}}$ calculada pela expressão:

$$
s^{2}=\sum_{i=1}^{n} \frac{\left(x_{i}-\bar{x}\right)^{2}}{n-1}
$$

A raiz quadrada da variância amostral é o chamado erro padrão amostral, utilizado para calcular o intervalo de confiança para a média.

Intervalo de confiança para a média: Ele fornece um intervalo de valores, centrado na média amostral, através da qual se julga, com um risco conhecido de erro, estar o parâmetro $\mu$ da população.

O cálculo do intervalo está baseado, portanto, na média aritmética; a precisão com que essa média foi obtida (medida através do erro padrão da média) é uma avaliação teórica que incorpora o risco de erro e que nesse caso é representado por "t" de Student. Assim, a expressão para o intervalo de confiança é:

$$
I C[\mu]_{95 \%}=\bar{x} \pm t_{v, 0.95} \frac{s}{\sqrt{n}}
$$

onde $\bar{x}$ é a média aritmética, $t$ é a o calculo que define o nivel de risco do intervalo, nesse caso $5 \%$ (95\% de confiança), calculado com $n-1=v$ graus de liberdade, s é o erro padrão da média e n é o número de observaçōes. Assim, obtém-se um intervalo de confiança para a média amostral que tem uma probabilidade de 0,95 de conter a verdadeira média populacional. A metodologia de intervalo de confiança pressupõe que os dados são provenientes de uma população com distribuição normal (simétrica). 
Uma vez que não foi possivel aplicar testes de comparações múltiplas para as variedades em estudo, devido à falta de informações sobre o delineamento do experimento e sobre a variação experimental devida ao acaso, porque trata-se de plantas em coleção, uma alternativa para comparar a igualdade ou não das respostas devidas às variedades pode ser feita através do estudo do intervalo de confiança. Se o intervalo de confiança para a média de determinada variável resposta ( por exemplo peso dos frutos), obtida com uma variedade, for coincidente com o intervalo de confiança para a média obtida com outra variedade, pode-se supor que não há diferença entre elas, sempre que as condições do experimento forem as mesmas deste trabalho, e com um risco de erro $\alpha$ (para este trabalho foi considerado um mínimo de 0,05 confiança de 0,95 ).

Uma análise gráfica dos intervalos de confiança para a média esclarece melhor essas comparações.

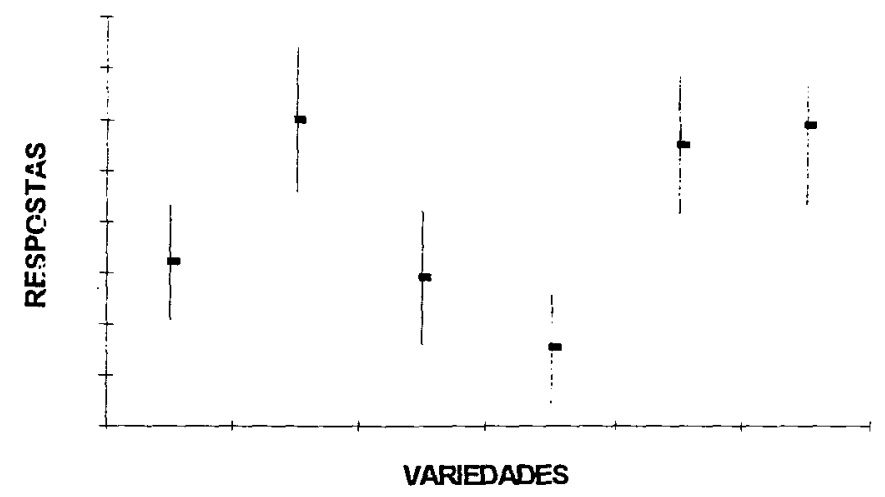

No gráfico cada linha corresponde a uma variedade de țangor ou de tangelo estudada; o comprimento de cada linha corresponde ao comprimento do intervalo de confiança obtido a um nivel de confiança de $95 \%$ e a barra central corresponde à média da variável resposta obtida para cada variedade em estudo. No exemplo simulado acima pode-se concluir que as variedades 
relativas às três linhas que ficaram abaixo do centro da figura diferem das três que ficaram acima do centro da figura e que dentro dos dois grupos não houve diferença entre as variedades (as três de baixo são iguais e as três de cima também).

Ao final foram feitos gráficos denominados raios de sol (sun ray plot) para mostrar o comportamento de cada variedade com relação às variáveis estudadas e para uma comparação com os padrões já conhecidos e aceitos para comercialização. Os tangores foram plotados ${ }^{2}$ sobre os valores conhecidos do tangor 'Murcott' e os tangelos plotados sobre os valores conhecidos do tangelo Orlando.

2 Plotados ou Plotar: Colocar pontos num gráfico. 
4 RESULTADOS E DISCUSSĀO

4.1 Ficha pomológica das variedades.

A seguir são apresentadas as fichas pomológicas de cada variedade: 
TANGOR DA ÍNDIA

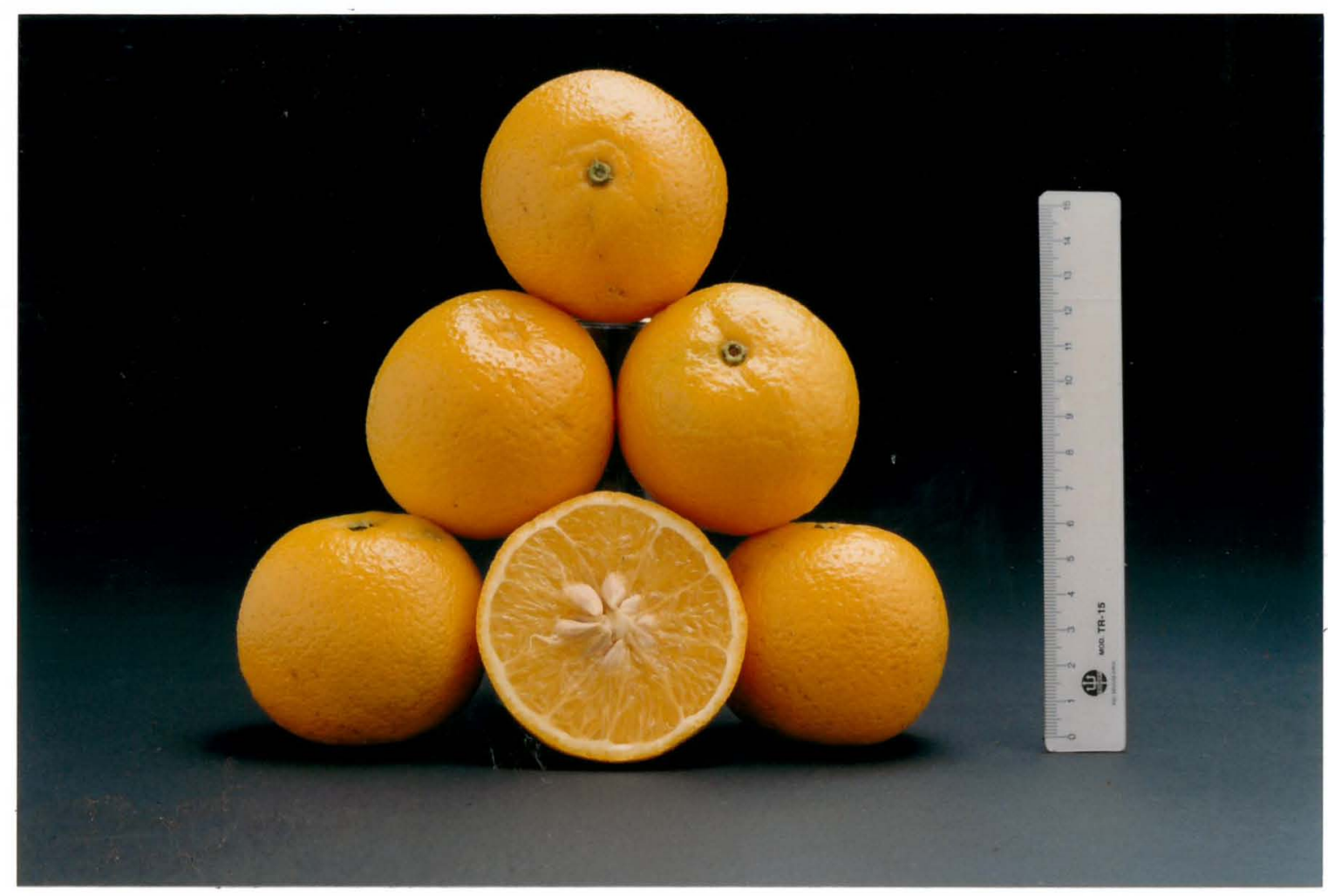

Variedade sem origem conhecida. Apresenta frutos de tamanho médio, coloração alaranjada, forma esferóide. Casca ligeiramente rugosa, aderente, com glândulas de óleo ligeiramente proeminentes. Ápice e base truncados.

Peso médio 132,81 g, polpa de coloração amarelo pálido alaranjado, com média de 18,95 sementes por fruto. Suco correspondendo a $49,21 \%$ do peso do fruto, com teores médios de brix de $11,82 \%$, acidez $1,18 \%$ e ratio 10,06. O indice tecnológico corresponde a $2,37 \mathrm{~kg}$ de sólidos solúveis/caixa. 
TANGOR SANTA MARIA MADALENA

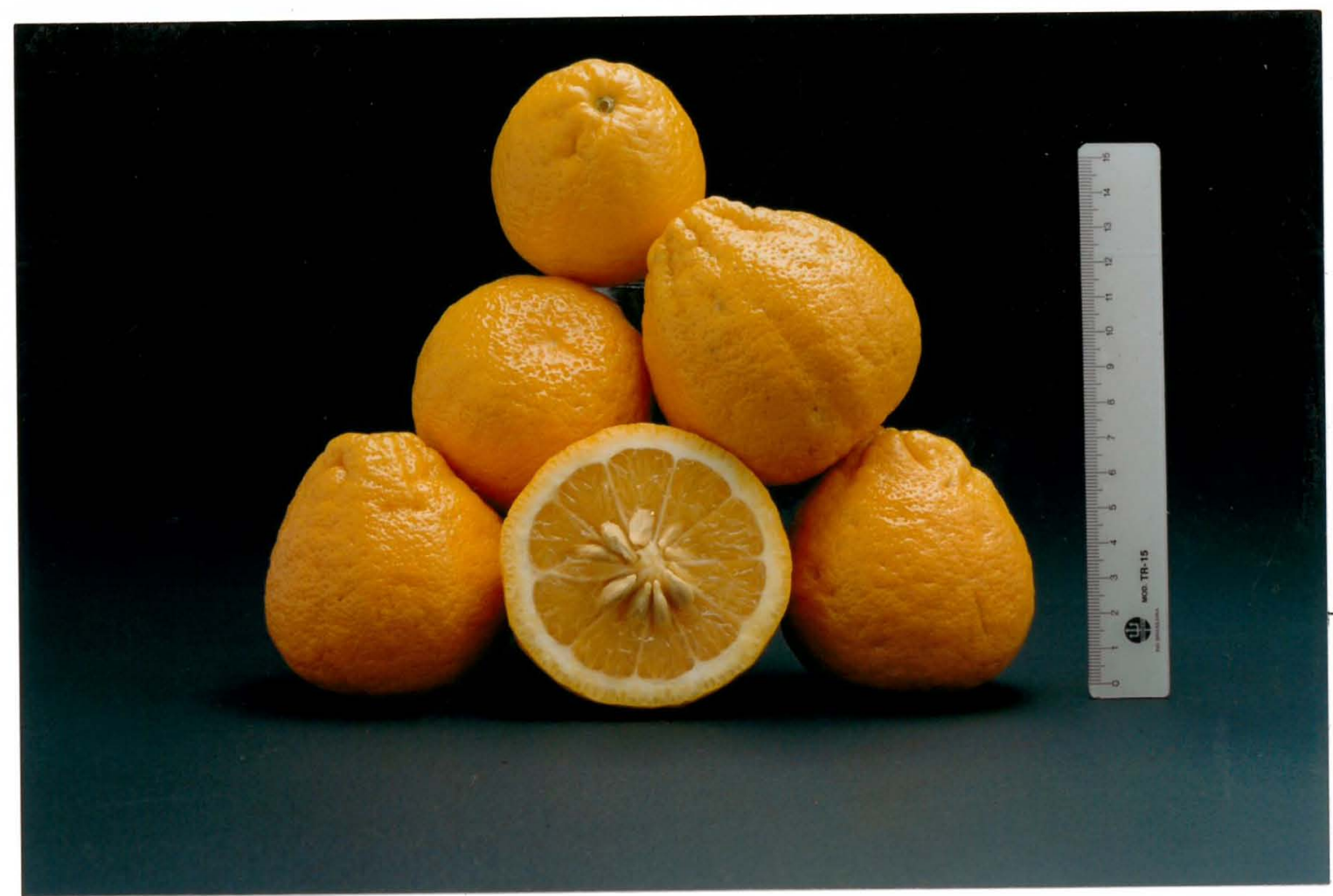

Variedade introduzida do Rio de Janeiro. "Apresenta frutos de tamanho médio a grande, coloração amarelada, forma periforme. Casca rugosa, aderente, com glândulas de óleo proeminentes. Ápice truncado e base concava com colarinho. Peso médio 155,07g, polpa de coloração amarelo pálido alaranjado, com a média de 11,50 sementes por fruto. Suco correspondendo a $41,99 \%$ do peso do fruto, com teores médios de brix de 15,45\%, acidez 1,22\% e ratio 12,78. O indice tecnológico corresponde a 2,66 kg de sólidos solúveis/caixa. 


\section{TANGOR ORTANIQUE}

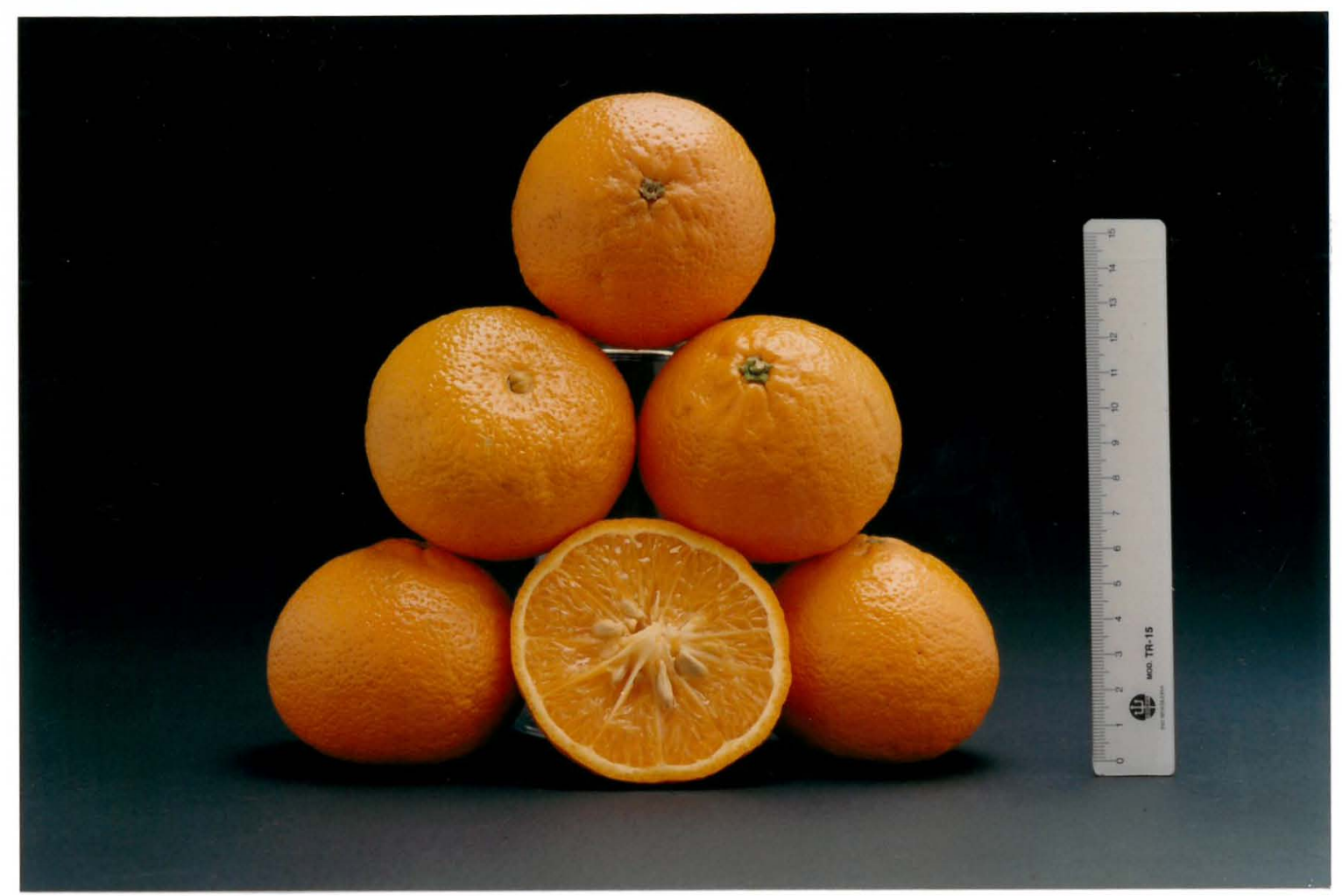

Variedade introduzida da Córsega. Apresenta frutos de tamanho médio a grande, coloração laranja avermelhada, forma oblata. Casca levemente rugosa, aderente, com glândulas de óleo proeminentes. Ápice truncado com umbigo e base convexa. Peso médio de 179,07g, polpa de coloração alaranjada, com média de 23,06 sementes por fruto. Suco correspondendo a $52,23 \%$ do peso do fruto, com teores médios de brix de 13,40\%, acidez 1,54\% e ratio 8,78. $\mathrm{O}$ indice tecnológico corresponde a $2,84 \mathrm{~kg}$ de sólidos solúveis/caixa. 


\section{TANGELO MINNEOLA}

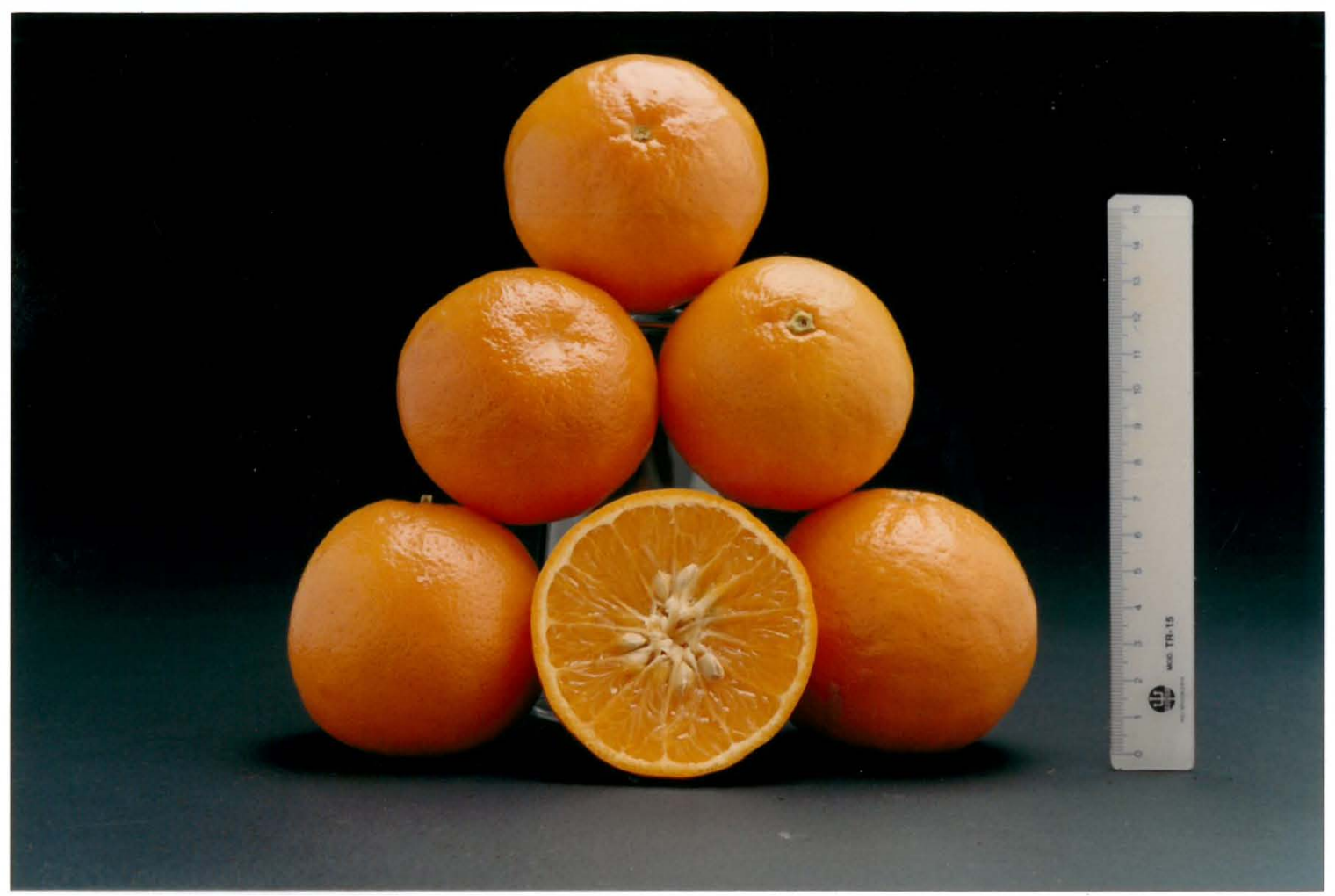

Variedade trazida do Departamento de Agricultura dos Estados Unidos (USDA), pelo Dr. Sylvio Moreira, no ano de 1948. Apresenta frutos de tamanho grande, coloração laranja avermelhado, forma oblata a esferóide. Casca lisa, aderente, com glândulas de óleo ligeiramente proeminentes. Ápice e base truncados. Peso médio de 230,72g, polpa de coloração alaranjada, com a média de 28,83 sementes por fruto. Suco correspondendo a $54,37 \%$ do peso do fruto, com teores médios de brix $11,67 \%$; acidez $1,71 \%$ e ratio 6,92 . O índice tecnológico corresponde a $2,59 \mathrm{~kg}$ de sólidos solúveis/caixa. 


\section{TANGELO SAMPSON}

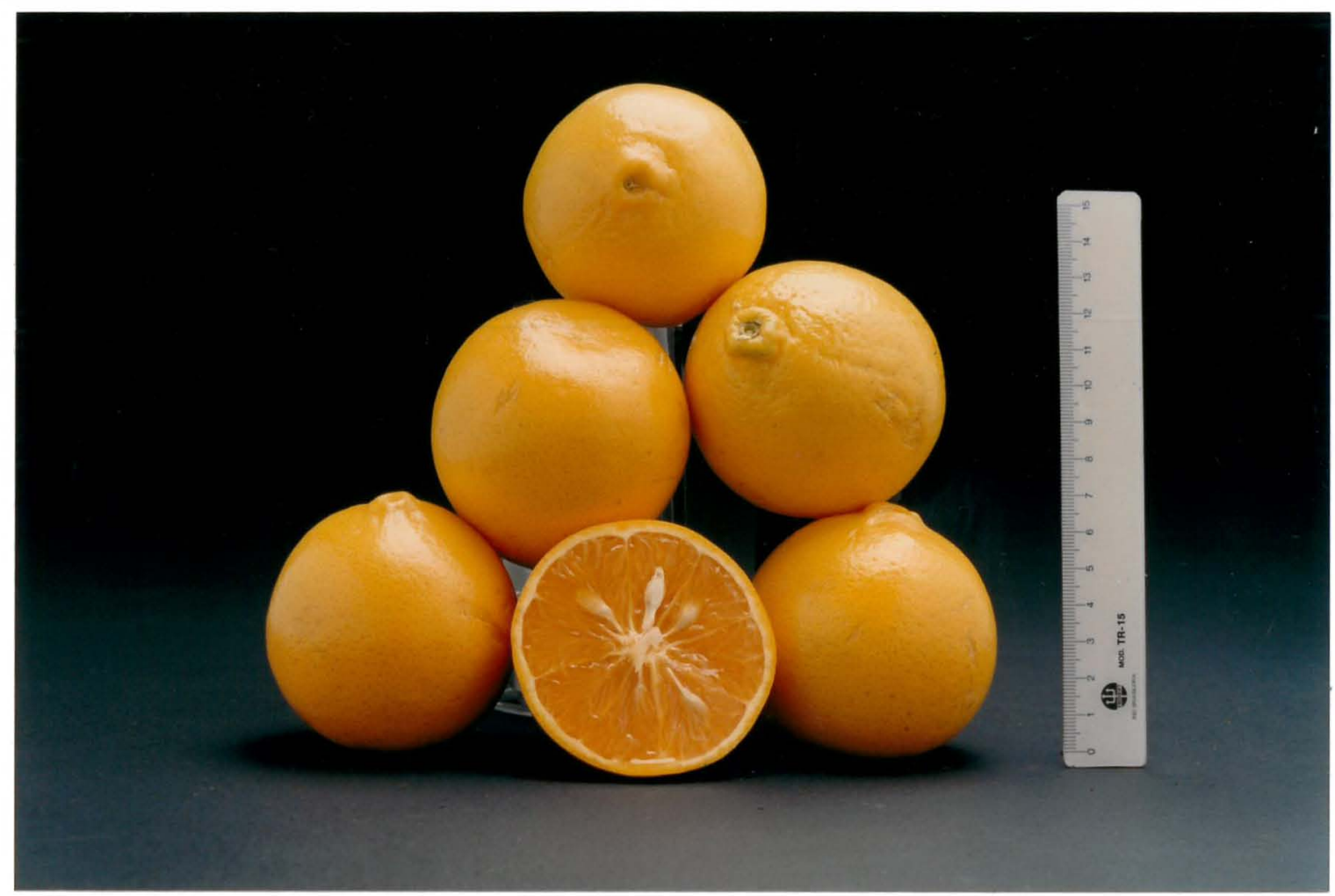

Variedade trazida do USDA, pelo Dr. Sylvio Moreira, no ano de 1948. Apresenta frutos de tamanho grande, coloração amarelada, forma oblata. Casca lisa, aderente, com glândulas menores de óleo ligeiramente proeminentes. Ápice truncado e base côncava com colarinho. Peso médio de 199,09g, polpa de coloração alaranjada, com a média de 23,38 sementes por fruto. Suco correspondendo a $54,65 \%$ do peso do fruto, com teores médios de brix de $12,19 \%$, acidez $1,72 \%$ e ratio 7,16 . O indice tecnológico corresponde a $2,71 \mathrm{~kg}$ de sólidos solúveis/caixa. 


\section{TANGELO SEMINOLE}

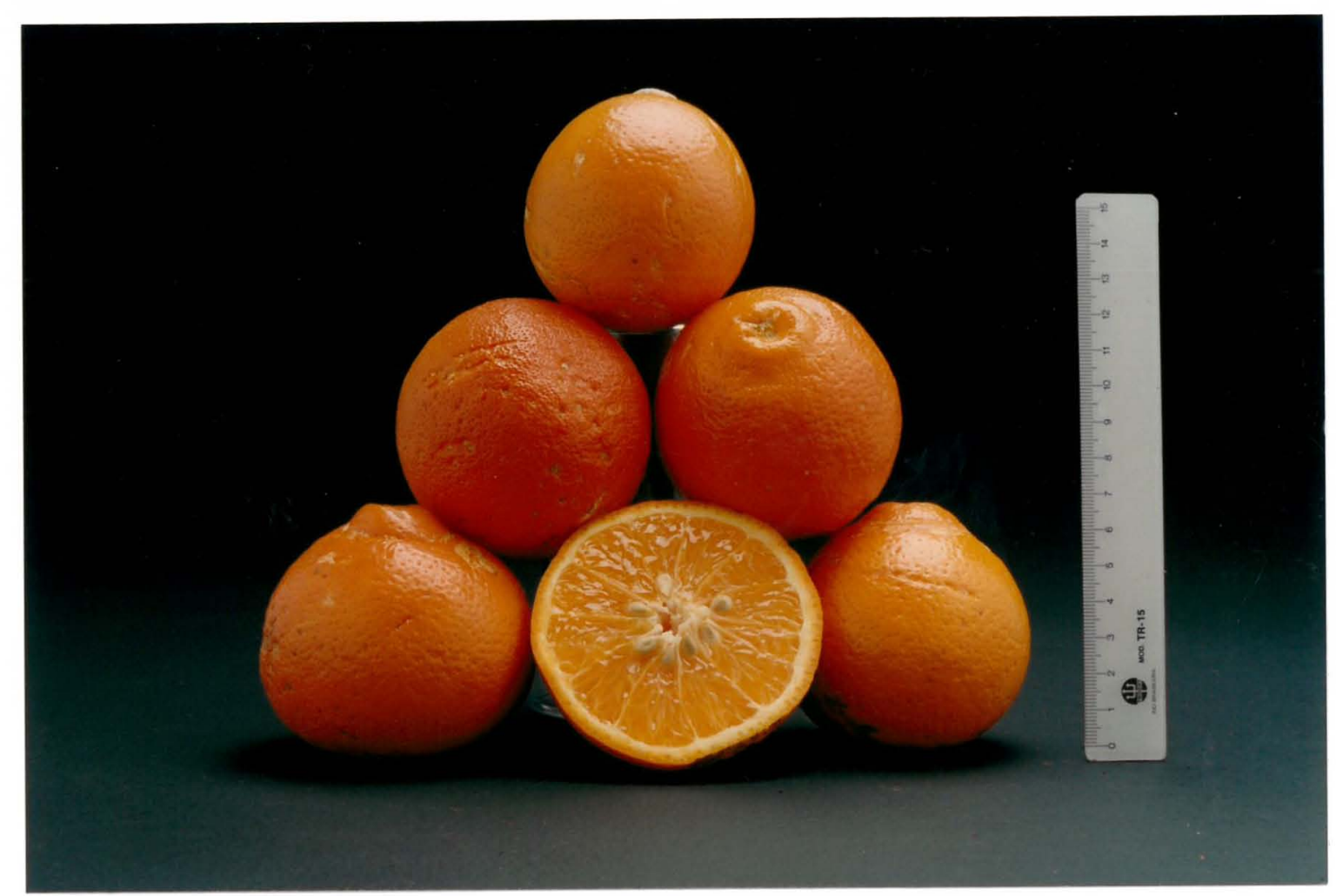

Variedade trazida do USDA, pelo Dr. Sylvio Moreira, no ano de 1948. Apresenta frutos de tamanho grande, coloração vermelho alaranjado, forma oblata. Casca ligeiramente rugosa, aderente, com glândulas de óleos ligeiramente proeminentes. Ápice truncado e base côncava com colarinho. Peso médio de 185,84g. Polpa de coloração alaranjada, com média de 12,42 sementes por fruto. Suco correspondendo à 56,03\% do peso do fruto, com teores médios de brix de $13,98 \%$, acidez $1,52 \%$ e ratio 9,37 . O indice tecnológico corresponde a 3,19 kg de sólidos solúveis / caixa. 


\section{2 Caracteristicas externas dos frutos}

\subsubsection{Altura dos frutos}

Embora não possa ser afirmado sobre diferenças estatisticamente significativas entre as variedades, observa-se pela Tabela 1 e Figura 1 que a maior média para altura dos frutos, no primeiro ano, foi obtida pelo tangelo Sampson $(7,62 \mathrm{~cm})$. A menor média, nesse ano, foi obtida pelo tangor da Índia, com valor de $5,98 \mathrm{~cm}$. No segundo ano a maior média ficou com o tangelo Seminole $(7,87 \mathrm{~cm})$, seguida do tangelo Sampson $(7,62 \mathrm{~cm})$. A menor média no segundo ano continuou com o tangor da Índia, $(5,93 \mathrm{~cm})$.

\subsubsection{Diâmetro dos frutos}

Quanto a diâmetro dos frutos, pode ser observado pela Tabela $1 \mathrm{e}$ Figura 1, no primeiro ano, que a maior média foi obtida pelo tangelo Minneola, $(7,50 \mathrm{~cm})$. A menor média, nesse ano, foi obtida pelo tangor da Índia, com valor de $6,50 \mathrm{~cm}$. No segundo ano esse resultado foi confirmado, ou seja, a posição dessas duas variedades ficou inalterada.

\subsubsection{Altura/diâmetro dos frutos}

A maior média para altura/diâmetro (H/D) dos frutos observando se a Tabela 1 e Figura 1, no primeiro ano, foi obtida pelo tangelo Sampson $(1,10$ $\mathrm{cm})$. A menor média, nesse ano, foi obtida pelo tangor Ortanique, com valor de $0,86 \mathrm{~cm}$. No segundo ano esse resultado foi confirmado para a menor média, que continuou sendo do Ortanique $(0,87 \mathrm{~cm})$, mas a maior média foi obtida pelo tangelo Seminole $(1,06 \mathrm{~cm})$. 
Confrontando a altura/diâmetro dos frutos, a maioria apresenta ser menor que 1. Segundo (Pio, 1997), trata-se de variedades com a mesma conformação das tangerinas comerciais. Dentre elas estão as variedades de tangores da Índia, Ortanique e o tangelo Minneola nos dois anos de estudo. O tangor Santa Maria Madalena e o tangelo Sampson somente no segundo ano de estudo, apresentaram conformação comercial para as tangerinas. A variedade de tangelo Seminole está fora do padrão como tangerina, nos dois anos de estudo, o que não inviabiliza o seu uso para utilização na indústria, por exemplo. 
Tabela 1 - Média, desvio padrāo e intervalo de confiança a um nivel de $95 \%$ para as variáveis (altura, diâmetro, altura/diâmetro e peso dos frutos) por variedade de tangores e tangelos nos anos de 1996 e 1997.

\begin{tabular}{|c|c|c|c|c|c|c|c|c|}
\hline \multirow{3}{*}{$\begin{array}{l}\text { VARIEDADES } \\
\text { ESTUDADAS }\end{array}$} & \multicolumn{4}{|c|}{$1^{\circ}$ ANO (1996) } & \multicolumn{4}{|c|}{$2^{\circ}$ ANO (1997) } \\
\hline & \multirow[b]{2}{*}{ MÉDIA } & \multicolumn{2}{|c|}{$\begin{array}{r}\text { INT.DE } \\
\text { CONFIANÇA } 95 \%\end{array}$} & \multirow[b]{2}{*}{ D.PADRÃO } & \multirow[b]{2}{*}{ MÉDIA } & \multicolumn{2}{|c|}{$\begin{array}{l}\text { INT.DE } \\
\text { CONFIANÇA 95\% }\end{array}$} & \multirow[b]{2}{*}{ D.PADRÃO } \\
\hline & & LIM.INF. & LIM.SUP & & & LIM.INF. & $\overline{\text { LIM.SUP }}$ & \\
\hline \multicolumn{9}{|c|}{ Altura dos frutos } \\
\hline $\begin{array}{l}\text { TANGOR DA } \\
\text { INDIA }\end{array}$ & 5,98 & 5,92 & 6,04 & 0,04 & $5, \overline{93}$ & 5,81 & 6,06 & 0,12 \\
\hline $\begin{array}{l}\text { TANGOR S.M. } \\
\text { MADALENA }\end{array}$ & 6,88 & 6,72 & 7,04 & 0,13 & 6,82 & 6,50 & 7,13 & 0,30 \\
\hline $\begin{array}{l}\text { TANGOR } \\
\text { ORTANIQUE }\end{array}$ & 6,36 & 6,29 & 6,43 & 0,05 & 6,47 & 6,21 & 6,72 & 0,24 \\
\hline $\begin{array}{l}\text { TANGELO } \\
\text { MINNEOLA }\end{array}$ & 6,96 & 6,89 & 7,03 & 0,05 & 7,37 & 7,26 & 7,48 & 0,10 \\
\hline $\begin{array}{l}\text { TANGELO } \\
\text { SAMPSON }\end{array}$ & 7,62 & 7,24 & 8,00 & 0,30 & 7,62 & 7,44 & 7,80 & 0,17 \\
\hline $\begin{array}{l}\text { TANGELO } \\
\text { SEMINOLE }\end{array}$ & 7,22 & 6,86 & 7,58 & 0,29 & 7,87 & 7,60 & 8,14 & 0,26 \\
\hline \multicolumn{9}{|c|}{ Diâmetro dos Frutos } \\
\hline $\begin{array}{l}\text { TANGOR DA } \\
\text { INDIA }\end{array}$ & 6,50 & 6,32 & 6,68 & 0,14 & 6,50 & 6,21 & 6,79 & 0,28 \\
\hline $\begin{array}{l}\text { TANGOR S.M. } \\
\text { MADALENA }\end{array}$ & 6,82 & 6,60 & 7,04 & 0,18 & 6,98 & 6,65 & 7,32 & 0,32 \\
\hline $\begin{array}{l}\text { TANGOR } \\
\text { ORTANIQUE }\end{array}$ & 7,34 & 7,10 & 7,58 & 0,19 & 7,25 & 6,88 & 7,62 & 0,36 \\
\hline $\begin{array}{l}\text { TANGELO } \\
\text { MINNEOLA }\end{array}$ & 7,50 & 7,38 & 7,62 & 0,10 & 8,30 & 8,17 & 8,43 & 0,13 \\
\hline $\begin{array}{l}\text { TANGELO } \\
\text { SAMPSON }\end{array}$ & 6,96 & 6,85 & 7,07 & 0,09 & 7,70 & 7,46 & 7,94 & 0,23 \\
\hline $\begin{array}{l}\text { TANGELO } \\
\text { SEMINOLE }\end{array}$ & 6,96 & 6,41 & 7,51 & 0,44 & 7,43 & 7,18 & 7,69 & 0,24 \\
\hline \multicolumn{9}{|c|}{ Altura/Diâmetro dos Frutos } \\
\hline $\begin{array}{l}\text { TANGOR DA } \\
\text { INDIA }\end{array}$ & 0,92 & 0,90 & 0,94 & 0,01 & 0,90 & 0,89 & 0,91 & 0,01 \\
\hline $\begin{array}{l}\text { TANGOR S.M. } \\
\text { MADALENA }\end{array}$ & 1,01 & 0,99 & 1,03 & 0,01 & 0,97 & 0,96 & 0,99 & 0,01 \\
\hline $\begin{array}{l}\text { TANGOR } \\
\text { ORTANIQUE }\end{array}$ & 0,86 & 0,84 & 0,89 & 0,02 & 0,87 & 0,85 & 0,89 & 0,02 \\
\hline $\begin{array}{l}\text { TANGELO } \\
\text { MINNEOLA }\end{array}$ & 0,93 & 0,91 & 0,94 & 0,01 & 0,89 & 0,87 & 0,91 & 0,02 \\
\hline $\begin{array}{l}\text { TANGELO } \\
\text { SAMPSON }\end{array}$ & 1,10 & 1,06 & 1,13 & 0,03 & 0,99 & 0,96 & 1,02 & 0,03 \\
\hline $\begin{array}{l}\text { TANGELO } \\
\text { SEMINOLE }\end{array}$ & 1,04 & 0,96 & 1,11 & 0,06 & 1,06 & 1,03 & 1,09 & 0,03 \\
\hline \multicolumn{9}{|c|}{ Peso dos Frutos } \\
\hline $\begin{array}{l}\text { TANGOR DA } \\
\text { INDIA }\end{array}$ & 133,28 & 125,17 & 141,39 & 6,53 & 132,35 & 127,42 & 137,28 & 4,70 \\
\hline $\begin{array}{l}\text { TANGOR S.M. } \\
\text { MADALENA }\end{array}$ & 149,00 & 142,80 & 155,20 & 4,99 & 161,15 & 143,51 & 178,79 & 16,81 \\
\hline $\begin{array}{l}\text { TANGOR } \\
\text { ORTANIQUE }\end{array}$ & 174,10 & 160,65 & 187,55 & 10,83 & 184,05 & 165,50 & 202,60 & 17,67 \\
\hline $\begin{array}{l}\text { TANGELO } \\
\text { MINNEOLA }\end{array}$ & 207,32 & 201,49 & 213,15 & 4,69 & 254,12 & 242,87 & 265,36 & 10,71 \\
\hline $\begin{array}{l}\text { TANGELO } \\
\text { SAMPSON }\end{array}$ & 182,78 & 180,22 & 185,34 & 2,06 & 215,40 & 194,36 & 236,44 & 20,05 \\
\hline $\begin{array}{l}\text { TANGELO } \\
\text { SEMINOLE }\end{array}$ & 162,06 & 143,65 & 180,47 & 14,83 & 209,62 & 195,36 & 223,87 & 13,59 \\
\hline
\end{tabular}




\subsubsection{Peso dos frutos}

O maior peso dos frutos, no primeiro ano (Tabela 1 e Figura 1), foi obtido pelo tangelo Minneola (207,32 g). A menor média, nesse ano, foi obtida pelo tangor da Índia, cujo valor foi $133,28 \mathrm{~g}$. No segundo ano esse resultado foi confirmado, ou seja, a posição dessas duas variedades ficou inalterada.

Comparando os resultados obtidos do peso dos frutos com os das variedades consideradas como padrão: tangor 'Murcott' e tangelo Orlando, observa-se que o peso dos frutos do tangor Santa Maria Madalena (com média de $149 \mathrm{~g}$ e intervalo de confiança de 142,80 a 155,20 g), no primeiro ano, está mais próximo do tangor 'Murcott', que apresenta uma média de $140 \mathrm{~g}$. No segundo ano esse resultado se distanciou, ou seja, o tangor Santa Maria Madalena superou o tangor 'Murcott' (com média de 161,15 g e intervalo de confiança de 143,51 a $178,79 \mathrm{~g})$. Nesse caso o intervalo de confiança não incluiu a média do tangor 'Murcott', o que sugere que são diferentes. O tangor da Índia, embora com uma média de $133,28 \mathrm{~g}$, obteve um intervalo de confiança entre 125,17 a $141,39 \mathrm{~g}$, no primeiro ano, o que indica que pode ser considerado igual ao da 'Murcott' quanto a média de peso de frutos; no segundo ano não pode ser afirmado o mesmo, pois, embora a média de peso desse tangor praticamente não tenha se modificado $(132,35 \mathrm{~g})$, seu intervalo de confiança $(127,42$ a $137,28 \mathrm{~g})$, não incluiu o peso do tangor 'Murcott'. O tangor Ortanique apresentou uma média e intervalo de confiança para peso de frutos muito acima do tangor 'Murcott', tanto no primeiro ano (média de $174,10 \mathrm{~g}$ ) e intervalo de confiança de 160,65 a 187,55 g, quanto no segundo ano (média de $184,05 \mathrm{~g})$ e intervalo de confiança de 165,50 a $202,60 \mathrm{~g}$, sugerindo, com um risco de 5\%, ser diferente do tangor 'Murcott'.

Com relação aos tangelos, observou-se que o peso dos frutos do tangelo Minneola foi superior ao do tangelo Orlando, tanto no primeiro ano, com média de 207,32 g e intervalo de confiança de 201,49 a 213,15 g, quanto no segundo ano, com média de 254,12 g e intervalo de confiança de 242,87 a $265,36 \mathrm{~g}$, não incluindo no intervalo de confiança, nos dois anos, a média de peso de frutos do tangelo Orlando, de $147 \mathrm{~g}$. O mesmo aconteceu com o tangelo Sampson, no primeiro ano, média de $182,78 \mathrm{~g}$ e intervalo de confiança de 
180,22 a $185,34 \mathrm{~g}$ e no segundo ano, média de 215,40 g e intervalo de confiança de 194,36 a 236,44 g. Já o tangelo Seminole, embora apresente média maior que o tangelo Orlando no primeiro ano $(162,06 \mathrm{~g})$, seu intervalo de confiança de 143,65 a 180,47 g sobrepõe a média do tangelo Orlando, podendo ser considerados iguais, baseando-se num risco de 5\%; no segundo ano esse resultado não se confirmou, ou seja, o tangelo Seminole superou o tangelo Orlando com média de 209,62 g e intervalo de confiança de 195,36 a 223,87 g. Aqui o intervalo de confiança não inclui a média do tangelo Orlando, o que sugere que são diferentes.

Ficou convencionado neste trabalho o chamado padrão comercial para determinados itens de todas as variedades consideradas. Por exemplo, para peso dos frutos, o padrāo comercial foi convencionado estar entre os valores obtidos desde a tangerina Mexerica 'do Rio' (130 g) até a laranja 'Baianinha' (168 g) (Figueiredo, 1991), intervalo esse que de um modo geral abrange a maioria dos pesos médios das tangerinas e laranjas comerciais.

Observando os pesos das variedades de tangores e tangelos que apresentam médias que estão entre 133,28 a 207,32 g no primeiro ano e entre 132,35 a $254,12 \mathrm{~g}$, no segundo ano foi observado que dentro desse limite, somente as variedades de tangelos e tangores que se destacaram foram os tangores da Índia com 133,28 e 132,35 g e Santa Maria Madalena com 149,00 e 161,15 g, nos dois anos de estudo. O tangelo Seminole apresentou o valor para peso de $162,06 \mathrm{~g}$ somente no primeiro ano. As outras variedades estudadas apresentaram média bem superior ao intervalo convencionado para as principais variedades tomadas como comparação e portanto estão fora de padrāo.

Uma visualização melhor da posição das variedades quanto à média e os intervalos de confiança para as variáveis altura, diâmetro, altura/diâmetro e peso dos frutos, nos dois anos, é dada pelas Figura 1. Cabe mencionar que as linhas que se sobrepõem no mesmo espaço podem ser consideradas iguais; as que estão em espaços não sobrepostos são diferentes, a nivel de intervalo de confiança. 

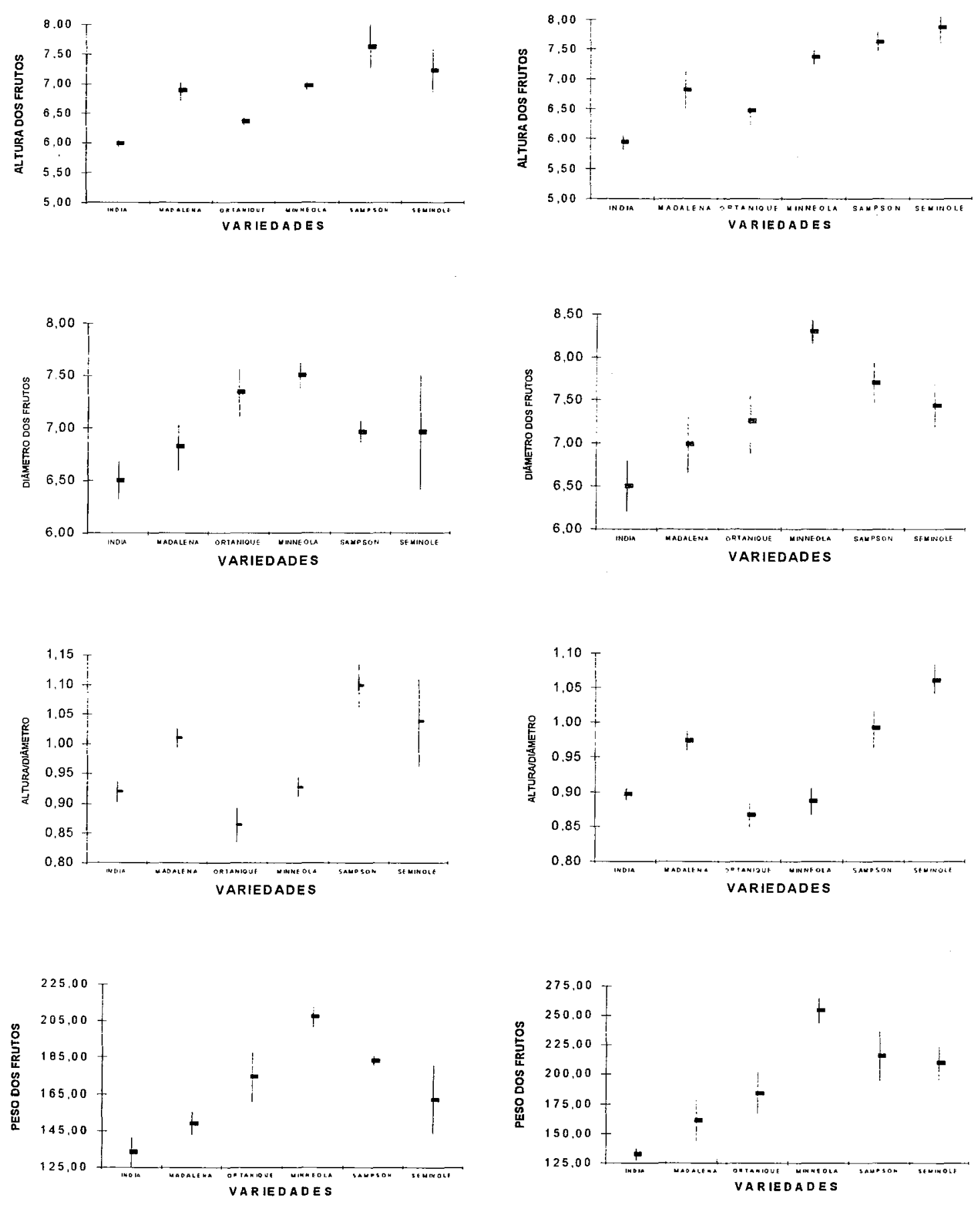

Ano 1 (1996)

Ano 2 (1997)

Figura 1 - Médias e Intervalos de Confiança (95\%) para as variáveis: altura, diâmetro, altura/diâmetro e peso dos frutos, obtidos das variedades nos anos de 1996 e 1997. 


\subsubsection{Coloração da casca}

Segundo o Atlas de Cores - Pflanzenfarben Atlas, de Biesalski (1957), o tangor da Índia apresenta a coloração da casca alaranjada, correspondendo ao código 4: 7,0: 1,5. Para o tangor Santa Maria Madalena e o tangelo Sampson que apresentam coloração da casca amarelada, o código correspondente é $3: 7,0: 1,0$.

O tangelo Minneola e o tangor Ortanique apresentam coloração da casca laranja avermelhada, correspondendo ao código 5: 6,4: 1,3. Já o tangelo Seminole apresentou a coloração vermelho alaranjado cujo código é $6: 6,5: 1,5$.

Para as variedades de tangores e tangelos estudados, a coloração está dentro das principais variedades comerciais de citros, que abrange desde uma coloração alaranjada claro ou amarelo alaranjado para a laranja 'Lima', atė alaranjada forte ou laranja avermelhada, para as laranjas 'Bahia', 'Baianinha', 'Valência' e as tangerinas 'Cravo' e 'Ponkan' (Figueiredo, 1991).

A cor laranja avermelhada do tangelo Minneola e tangor Ortanique, e o vermelho alaranjado do tangelo Seminole, constituem material bastante interessante que precisa ser levado ao consumidor para a sua apreciação, a fim de corrigir a errada impressão de que o fruto avermelhado é sinônimo de fruto em estádio "de passado".

\subsubsection{Morfologia}

O tangor Santa Maria Madalena possui forma periforme, ápice truncado e base concava com colarinho; o Ortanique tem a forma oblata, ápice truncado com umbigo e base convexa e o tangor da Índia tem a forma esferóide, ápice e base truncados.

Os tangelos Seminole e Sampson possuem a forma oblata, ápice truncado e base côncava com colarinho; o Minneola possui forma oblata a esferóide, ápice e base truncados. 


\subsection{Caracteristicas internas dos frutos}

\subsubsection{Sólidos solúveis (brix)}

Pode ser observado pela Tabela 2 e Figura 2, que a maior média para brix dos frutos, no primeiro ano, foi obtida pelo tangor Santa Maria Madalena $(15,02 \%)$. A menor média, nesse ano, foi obtida pelo tangor da Índia, com valor de $11,44 \%$. No segundo ano o resultado para maior média foi confirmado, ou seja, a posição dessa variedade ficou inalterada. A menor média ficou com o tangelo Minneola com o valor de 11,55 \%.

Comparando - se os resultados obtidos com os das variedades consideradas como padrão: tangor 'Murcott' e tangelo Orlando, observa-se que o brix dos frutos do tangor Ortanique, no primeiro ano, com média de $12,88 \%$ e intervalo de confiança de 12,00 a $13,76 \%$ está mais próximo do tangor 'Murcott', que apresenta uma média de 12,60\%, podendo assim ser considerados iguais, já que o intervalo de confiança do tangor Ortanique inclui a média do tangor 'Murcott'. No segundo ano foi o tangor da Índia que foi igual ao tangor 'Murcott' com média de 12,20 \% e intervalo de confiança de 10,34 a $14,06 \%$, que inclui a média do tangor 'Murcott'. Nenhum outro tangor foi igual à 'Murcott' quanto ao brix, nos dois anos. Quando se comparam os intervalos de confiança, o Santa Maria Madalena e o Ortanique tiveram resultados maiores.

Com relação aos tangelos, observa-se que no primeiro ano nenhum deles pode ser considerado igual ao tangelo Orlando, com média de $13,30 \%$ quanto ao brix. Os resultados obtidos mostraram que os tangelos Minneola e o Sampson apresentaram médias menores e que o Seminole apresentou médias maiores, tendo todos intervalo de confiança que não inclui a média do tangelo Orlando. No segundo ano o tangelo Seminole, com média de $13,53 \%$ e intervalo de confiança de 12,48 a $14,59 \%$ pode ser igual ao tangelo Orlando. Os demais apresentaram médias menores e intervalos de confiança que não incluem a média do tangelo Orlando. 
Tabela 2 - Médias, desvio padrão e intervalo de confiança a um nivel de 95\% para as variáveis (sólidos solúveis, acidez e ratio) por variedade de tangores e tangelos nos anos de 1996 e 1997.

\begin{tabular}{|c|c|c|c|c|c|c|c|c|}
\hline \multirow{3}{*}{$\begin{array}{l}\text { VARIEDADES } \\
\text { ESTUDADAS }\end{array}$} & \multicolumn{4}{|c|}{$1^{\circ}$ ANO (1996) } & \multicolumn{4}{|c|}{$2^{\circ}$ ANO (1997) } \\
\hline & \multirow[b]{2}{*}{ MEDIA } & \multicolumn{2}{|c|}{$\begin{array}{r}\text { INT.DE CONFIANÇA } \\
95 \% \\
\end{array}$} & \multirow[b]{2}{*}{ D.PADRÄO } & \multirow[b]{2}{*}{ MÉDIA } & \multicolumn{2}{|c|}{$\begin{array}{l}\text { INT.DE CONFIANÇA } \\
95 \%\end{array}$} & \multirow[b]{2}{*}{ D.PADKAOO } \\
\hline & & LIM.INF. & LIM.SUP. & & & LIM.INF. & LIM.SUP. & \\
\hline \multicolumn{9}{|c|}{ Sólidos Solúveis - brix $(\%)$} \\
\hline TANGOR DA INDIA & 11,44 & 10,65 & 12,23 & 0,64 & 12,20 & 10,34 & 14,06 & 1,77 \\
\hline $\begin{array}{l}\text { TANGOR S.M. } \\
\text { MADALENA }\end{array}$ & 15,02 & 13,59 & 16,45 & 1,15 & 15,88 & 14,49 & 17,28 & 1,33 \\
\hline $\begin{array}{l}\text { TANGOR } \\
\text { ORTANIQUE }\end{array}$ & 12,88 & 12,00 & 13,76 & 0,71 & 13,92 & 12,87 & 14,97 & 1,00 \\
\hline $\begin{array}{l}\text { TANGELO } \\
\text { MINNEOLA }\end{array}$ & 11,80 & 11,22 & 12,38 & 0,47 & 11,55 & 11,33 & 11,77 & 0,21 \\
\hline $\begin{array}{l}\text { TANGELO } \\
\text { SAMPSON }\end{array}$ & 12,08 & 11,49 & 12,67 & 0,48 & 12,30 & 11,62 & 12,98 & 0,65 \\
\hline $\begin{array}{l}\text { TANGELO } \\
\text { SEMINOLE } \\
\end{array}$ & 14,44 & 13,73 & 15,15 & 0,57 & 13,53 & 12,48 & 14,59 & 1,00 \\
\hline \multicolumn{9}{|c|}{ Acidez Total (\%) } \\
\hline TANGOR DA INDIA & 1,24 & 1,16 & 1,33 & 0,07 & 1,13 & 1,02 & 1,23 & 0,10 \\
\hline $\begin{array}{l}\text { TANGOR S.M. } \\
\text { MADALENA }\end{array}$ & 1,25 & 1,19 & 1,31 & 0,05 & 1,19 & 1,02 & 1,36 & 0,16 \\
\hline $\begin{array}{l}\text { TANGOR } \\
\text { ORTANIQUE }\end{array}$ & 1,46 & 1,33 & 1,59 & 0,11 & 1,62 & 1,47 & 1,76 & 0,14 \\
\hline $\begin{array}{l}\text { TANGELO } \\
\text { MINNEOLA }\end{array}$ & 1,84 & 1,56 & 2,11 & 0,22 & 1,59 & 1,39 & 1,80 & 0,20 \\
\hline $\begin{array}{l}\text { TANGELO } \\
\text { SAMPSON }\end{array}$ & 1,86 & 1,79 & 1,93 & 0,06 & 1,58 & 1,42 & 1,73 & 0,15 \\
\hline $\begin{array}{l}\text { TANGELO } \\
\text { SEMINOLE }\end{array}$ & 1,73 & 1,58 & 1,89 & 0,13 & 1,32 & 1,19 & 1,45 & 0,12 \\
\hline \multicolumn{9}{|c|}{ "Ratio" } \\
\hline TANGOR DA INDIA & 9,20 & 8,08 & 10,33 & 0,91 & 10,93 & 8,81 & 13,05 & 2,02 \\
\hline $\begin{array}{l}\text { TANGOR S.M. } \\
\text { MADALENA }\end{array}$ & 11,99 & 10,59 & 13,39 & 1,13 & 13,57 & 11,32 & 15,82 & 2,14 \\
\hline $\begin{array}{l}\text { TANGOR } \\
\text { ORTANIQUE }\end{array}$ & 8,89 & 7,59 & 10,20 & 1,05 & 8,67 & 7,77 & 9,57 & 0,86 \\
\hline $\begin{array}{l}\text { TANGELO } \\
\text { MINNEOLA }\end{array}$ & 6,52 & 5,41 & 7,63 & 0,89 & 7,33 & 6,42 & 8,23 & 0,86 \\
\hline $\begin{array}{l}\text { TANGELO } \\
\text { SAMPSON }\end{array}$ & 6,49 & 6,14 & 6,85 & 0,29 & 7,84 & 7,24 & 8,43 & 0,57 \\
\hline $\begin{array}{l}\text { TANGELO } \\
\text { SEMINOLE }\end{array}$ & 8,37 & 7,33 & 9,40 & 0,83 & 10,37 & 8,57 & 12,17 & 1,72 \\
\hline
\end{tabular}


As variedades de tangores e tangelos apresentam médias de brix entre (11,44 a 15,88 \%) nos dois anos de estudo. Segundo (Figueiredo,1991), as principais variedades comerciais, considerando-se as laranjas $\mathrm{e}$ as tangerinas, apresentam médias de brix entre 9,9\% (laranja 'Rubi') a 13,2\% (laranja 'Bahia'). Assim todas as variedades estudadas podem ser consideradas adequadas nos anos de 1996 e 1997, quanto a essa característica.

\subsubsection{Acidez total}

Pode ser observado pela Tabela 2 e Figura 2, que a maior média para acidez dos frutos, no primeiro ano, foi obtida pelo tangelo Sampson (1,86 $\%$ ). A menor média, nesse ano, foi obtida pelo tangor da Î́ndia, com valor de $1,24 \%$. No segundo ano o tangor Ortanique apresentou a maior média, de 1,62 $\%$, mas a menor foi também do tangor da Índia $(1,13 \%)$.

Comparando os resultados obtidos com os das variedades consideradas como padrão: tangor 'Murcott' e tangelo Orlando, observa-se que, quanto à acidez dos frutos, nenhum dos tangores, nos dois anos, se aproximou do tangor 'Murcott', que apresenta uma acidez média de 0,92\%. Todos os materiais aqui estudados apresentaram média de acidez maior que essa, e nenhum dos intervalos de confiança obtidos incluiu esse valor.

Com relação aos tangelos, ocorreu fato semelhante. Todos os tangelos estudados, nos dois anos, apresentaram média de acidez acima da média do tangelo Orlando, que é de 0,97\%. Também, nenhum intervalo de confiança incluiu esse valor.

Observando as variedades de tangores e tangelos que apresentam porcentagem de acidez entre $(1,13$ a $1,86 \%)$, verificou-se que todos eles são considerados inadequados, porque os resultados obtidos estão discordantes daqueles citados por (Figueiredo, 1991), onde os valores médios para acidez situam-se entre 0,12\% ( laranja 'Lima') a 1,05\% ( laranja Valência'). 


\subsubsection{Relaçāo sólidos solúveis: acidez (ratio)}

$\mathrm{Na}$ Tabela 2 e Figura 2, verifica-se que a maior média para ratio, no primeiro ano, foi obtida pelo tangor Santa Maria Madalena $(11,99)$. A menor média, nesse ano, foi obtida pelo tangelo Sampson $(6,49)$, seguido do tangelo Minneola $(6,52)$. No segundo ano esse resultado foi confirmado para a maior média, que continuou sendo o tangor Santa Maria Madalena (13,57), mas a menor média foi obtida pelo Minneola $(7,33)$, seguido do Sampson $(7,84)$.

Comparando os resultados obtidos com os das variedades consideradas como padrão: tangor 'Murcott' e tangelo Orlando, observou - se que, no primeiro ano, nenhum tangor se aproximou do valor médio para tangor 'Murcott' $(13,70)$ ou mesmo com relação ao intervalo de confiança; jā no segundo ano o ratio do tangor Santa Maria Madalena com valor médio de 13,57 e intervalo de confiança de 11,32 a 15,82 esteve mais próximo do tangor 'Murcott', podendo ser considerados iguais, já que o intervalo de confiança do tangor Santa Maria Madalena inclui a média do tangor 'Murcott'. Nenhum outro tangor foi semelhante ao tangor 'Murcott' quanto ao ratio, nos dois anos, quando se comparam os intervalos de confiança. Todos apresentaram médias de ratio com valores inferiores.

Com relação aos tangelos, observou-se que nem no primeiro, nem no segundo ano, nenhum deles pode ser considerado igual ao tangelo Orlando cuja média para ratio é de 13,71. Todos apresentaram médias inferiores.

$\mathrm{O}$ ratio indica o momento da colheita dos frutos. Quando a finalidade é industrialização, por exemplo, eles podem ser colhidos quando o ratio for igual ou maior que 11,5 (Salibe, 1974). Observando os resultados obtidos com as variedades em estudo, concluiu-se que a maioria delas apresenta ratio inadequado para a indústria de suco. Apenas o tangor Santa Maria Madalena apresentou valores médios adequados (11,99 em 1996 e 13,57 em 1997) para essa caracteristica. As outras variedades de tangores e todas as variedades de tangelos foram consideradas inadequadas porque apresentavam um ratio menor que $(11,5)$, na época da sua completa maturação. 
Verificando os resultados das análises feitas quinzenalmente, concluiu-se que o tangor Santa Maria Madalena pode ser colhido a partir do mês de agosto (de acordo com o primeiro ano de estudo) e a partir do mês de julho (no caso do segundo ano). A variedade tangor da Índia, apesar da média ser inferior ao padrão e considerando-se apenas os valores obtidos no segundo ano, poderá ser colhida a partir do mês de agosto (apresentou ratio $11,5 \mathrm{em}$ agosto e 14,6 em setembro).

Igual fato ocorreu para o tangelo Seminole, com ratio 12,4 obtido no mês de agosto e 12,3 no mês setembro, indicando que poderá ser colhido a partir do mês de agosto (Tabela 13). De uma maneira geral houve um acréscimo quanto ao ratio para as variedades em estudo.

Uma visualização melhor da posição das variedades quanto à média e os intervalos de confiança para as variáveis sólidos solúveis (brix), acidez total e ratio dos frutos, nos dois anos, pode ser conseguida na Figura 2.

\subsubsection{Rendimento de suco}

Observa-se, pela Tabela 3 e Figura 3, que a maior média para rendimento de suco, no primeiro ano, foi obtida pelo tangelo Seminole com valor de 57,48\%. A menor média, nesse ano, foi obtida pelo tangor Santa Maria Madalena $(41,42 \%)$. No segundo ano esse resultado foi confirmado para a menor média, que continuou sendo do Santa Maria Madalena $(42,57 \%)$, mas a maior média foi obtida pelo tangelo Sampson $(56,18 \%)$. 

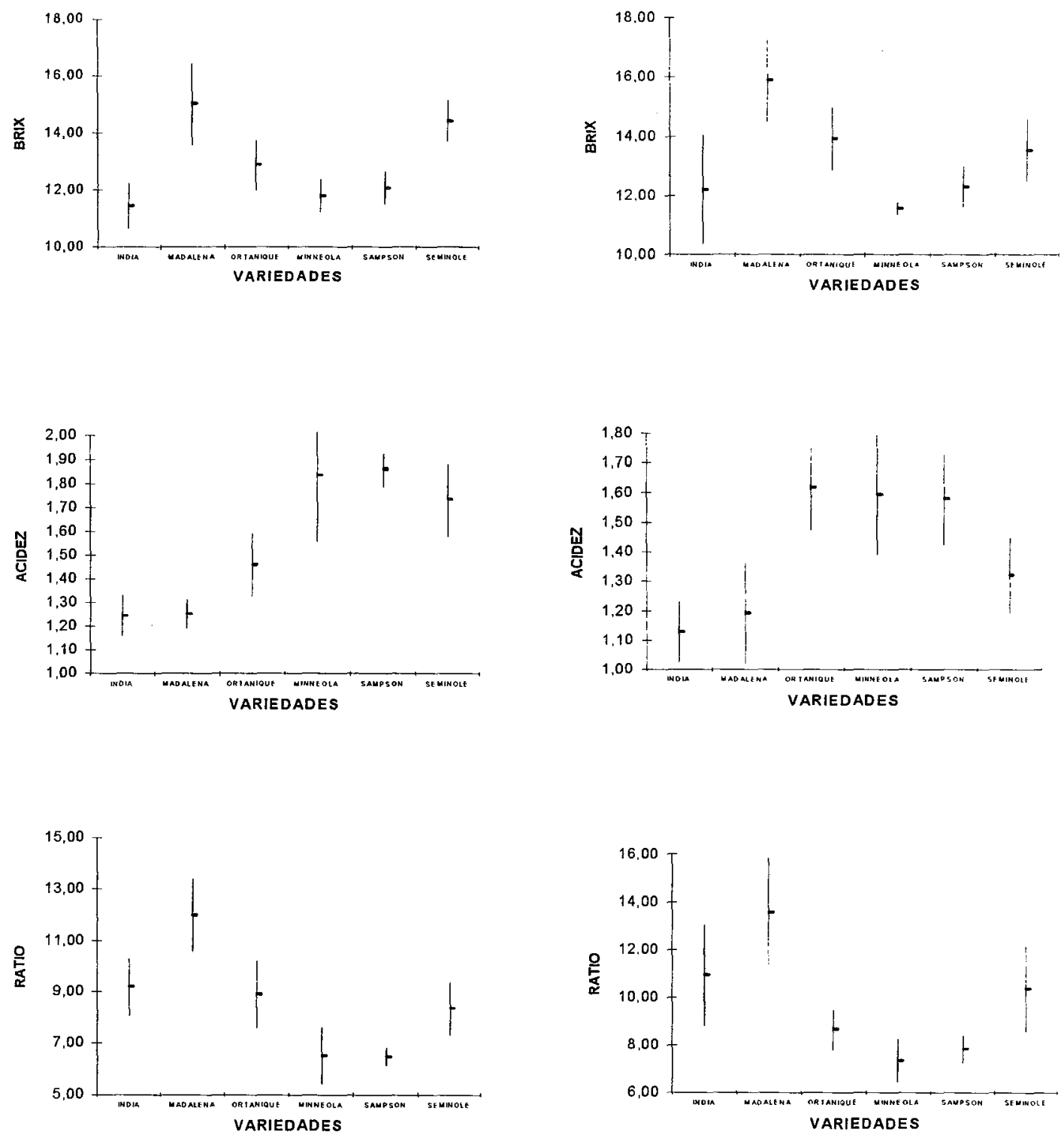

Ano 1 (1996)

Ano 2 (1997)

Figura 2 - Médias e intervalos de confiança (95\%) para as variáveis: sólidos solúveis (brix), acidez total e ratio, obtidos das variedades nos anos de 1996 e 1997. 
Comparando os resultados obtidos com os das variedades consideradas como padrão: tangor 'Murcott' e tangelo Orlando, observa-se que o rendimento do suco dos frutos do tangor da Índia no primeiro, 48,48 \% e intervalo de confiança de 47,59 a 49,37 \% está mais próximo do tangor 'Murcott', que apresenta uma média de $48 \%$, podendo ser considerados iguais, já que o intervalo de confiança do tangor da Índia incluiu a média do tangor 'Murcott'. No segundo ano esse resultado não se confirmou, ou seja, o tangor da Índia superou o tangor 'Murcott' com média de 49,95\% e intervalo de confiança de 48,32 a 51,58 \%. Esse valor não inclui a média do tangor 'Murcott', o que sugere que são diferentes, embora esses valores sejam altamente desejáveis. Nenhum outro tangor foi igual ao tangor 'Murcott' quanto ao rendimento de suco, nos dois anos, quando se comparam os intervalos de confiança: o tangor Santa Maria Madalena teve resultado menor e o Ortanique maior.

Com relação aos tangelos, foi observado que o rendimento de suco do tangelo Seminole e do Minneola pode ser considerado igual ao do tangelo Orlando cujo valor médio é de $57,33 \%$, uma vez que no primeiro ano, o Seminole, apresentou média de 57,48 \% e intervalo de confiança de 56,60 a $58,36 \%$ e o tangelo Minneola obteve média de 55,38 \% e intervalo de confiança de 52,82 a $57,94 \%$. No segundo ano o tangelo Sampson com média de 56,18\% e intervalo de confiança de 54,26 a $58,10 \%$ e o tangelo Seminole com média de $54,58 \%$ e intervalo de confiança de 49,99 a 59,18\% também pode ser considerados iguais ao tangelo Orlando. $\mathrm{O}$ mesmo não aconteceu com o tangelo Sampson, no primeiro ano, com média de 53,12\% e intervalo de confiança de 50,14 a $56,10 \%$ e com o tangelo Minneola no segundo ano, com média de $53,37 \%$ e intervalo de confiança de 51,13 a $55,60 \%$, cujos valores não incluem a média do tangelo Orlando, o que sugere que são diferentes. Para os tangores e para os tangelos, todo valor superior a $48 \%$ de suco é de grande interesse. 
Tabela 3 - Médias, desvio padrão e intervalo de confiança a um nivel de 95\% para as variáveis (rendimento de suco, indice tecnológico e nümero de sementes ) por variedade tangores e tangelos nos anos de $1996 \mathrm{e}$ 1997.

\begin{tabular}{|c|c|c|c|c|c|c|c|c|}
\hline \multirow{3}{*}{$\begin{array}{l}\text { VARIEDADES } \\
\text { ESTUDADAS }\end{array}$} & \multicolumn{4}{|c|}{$1^{\circ} \mathrm{ANO}$} & \multicolumn{4}{|c|}{$2^{\circ} \mathrm{ANO}$} \\
\hline & \multirow{2}{*}{ MÉDIA } & \multirow{2}{*}{\multicolumn{2}{|c|}{$\begin{array}{r}\text { INT.DE CONFIANÇA } \\
95 \%\end{array}$}} & \multirow{3}{*}{ D.PADRÃO } & \multirow{2}{*}{ MÉDIA } & \multirow{2}{*}{\multicolumn{2}{|c|}{$\begin{array}{l}\text { INT.DE CONFIANCA } \\
95 \%\end{array}$}} & \multirow{2}{*}{ D.PADRÄC } \\
\hline & & & & & & & & \\
\hline \multicolumn{8}{|c|}{ Rendimento de suco (\%) } & \\
\hline TANGOR DA INDIA & 48,48 & 47,59 & 49,37 & 0,72 & 49,95 & 48,32 & 51,58 & 1,56 \\
\hline $\begin{array}{l}\text { TANGOR S.M. } \\
\text { MADALENA }\end{array}$ & 41,42 & 40,41 & 42,43 & 0,81 & 42,57 & 41,46 & 43,68 & 1,06 \\
\hline $\begin{array}{l}\text { TANGOR } \\
\text { ORTANIQUE }\end{array}$ & 51,30 & 49,49 & 53,11 & 1,46 & 53,17 & 50,64 & 55,59 & 2,41 \\
\hline $\begin{array}{l}\text { TANGELO } \\
\text { MINNEOLA }\end{array}$ & 55,38 & 52,82 & 57,94 & 2,06 & 53,37 & 51,13 & 55,60 & 2,13 \\
\hline $\begin{array}{l}\text { TANGELO } \\
\text { SAMPSON }\end{array}$ & 53,12 & 50,14 & 56,10 & 2,40 & 56,18 & 54,26 & 58,10 & 1,83 \\
\hline $\begin{array}{l}\text { TANGELO } \\
\text { SEMINOLE }\end{array}$ & 57,48 & 56,60 & 58,36 & 0,71 & 54,58 & 49,99 & 59,18 & 4,38 \\
\hline \multicolumn{9}{|c|}{ Índice Tecnológico } \\
\hline TANGOR DA INDIA & 2,26 & 2,07 & 2,44 & 0,15 & 2,49 & 2,08 & 2,90 & 0,39 \\
\hline $\begin{array}{l}\text { TANGOR S.M. } \\
\text { MADALENA }\end{array}$ & 2,57 & 2,35 & 2,80 & 0,18 & 2,76 & 2,52 & 2,99 & 0,22 \\
\hline $\begin{array}{l}\text { TANGOR } \\
\text { ORTANIQUE }\end{array}$ & 2,66 & 2,47 & 2,84 & 0,15 & 3,03 & 2,72 & 3,33 & 0,29 \\
\hline $\begin{array}{l}\text { TANGELO } \\
\text { MINNEOLA }\end{array}$ & 2,67 & 2,44 & 2,91 & 0,19 & 2,51 & 2,40 & 2,62 & 0,10 \\
\hline $\begin{array}{l}\text { TANGELO } \\
\text { SAMPSON }\end{array}$ & 2,61 & 2,50 & 2,72 & 0,09 & 2,82 & 2,69 & 2,95 & 0,12 \\
\hline $\begin{array}{l}\text { TANGELO } \\
\text { SEMINOLE }\end{array}$ & 3,39 & 3,24 & 3,53 & 0,11 & 3,00 & 2,82 & 3,19 & 0,17 \\
\hline \multicolumn{9}{|c|}{ Número de sementes } \\
\hline TANGOR DA INDIA & 20,36 & 18,34 & 22,38 & 1,63 & 17,57 & 13,06 & 22,07 & 4,30 \\
\hline $\begin{array}{l}\text { TANGOR S.M. } \\
\text { MADALENA }\end{array}$ & 10,44 & 8,90 & 11,98 & 1,24 & 12,57 & 8,71 & 16,43 & 3,68 \\
\hline $\begin{array}{l}\text { TANGOR } \\
\text { ORTANIQUE }\end{array}$ & 21,96 & 16,62 & 27,30 & 4,30 & 24,17 & 18,73 & 29,60 & 5,18 \\
\hline $\begin{array}{l}\text { TANGELO } \\
\text { MINNEOLA }\end{array}$ & 29,80 & 22,16 & 37,44 & 6,16 & 27,87 & 20,79 & 34,94 & 6,74 \\
\hline $\begin{array}{l}\text { TANGELO } \\
\text { SAMPSON }\end{array}$ & 22,40 & 20,53 & 24,27 & 1,50 & 24,37 & 14,96 & 33,77 & 8,96 \\
\hline $\begin{array}{l}\text { TANGELO } \\
\text { SEMINOLE }\end{array}$ & 17,12 & 13,50 & 20,74 & 2,91 & 7,73 & 3,17 & 12,30 & 4,35 \\
\hline
\end{tabular}


Das variedades de tangores e tangelos estudadas, a maioria apresentou médias adequadas para rendimento de suco, tanto para a comercialização in natura como para a industrialização. Foi convencionado o intervalo ideal para porcentagem de suco escolhendo-se para comparação dentre as principais variedades comerciais de citros aquelas que estão com média para esse parâmetro entre 45\% (laranja 'Lima') a 52\% (laranja 'Pêra') (Figueiredo, 1991).

Os valores obtidos mostraram que os tangores Ortanique $151,30 \mathrm{e}$ $53,17 \%)$ e da Índia $(48,48$ e 49,95\%), são bastante adequados. Apenas o tangor Santa Maria Madalena, com média de 41,42 e $42,57 \%$, não foi adequado quanto ao rendimento do suco, principalmente quando os frutos são destinados a industrialização. Todos os tangelos estão com valores excelentes, variando de $53,12 \%$ a $57,48 \%$, nos dois anos estudados.

\subsection{5 Índice tecnológico}

Pode ser observado pela Tabela 3 e Figura 3, que a maior média para indice tecnológico, no primeiro ano, foi obtida pelo tangelo Seminole $(3,39)$. A menor média, nesse ano, foi obtida pelo tangor da Índia $(2,26)$. No segundo ano, a maior média foi obtida pelo tangor Ortanique $(3,03)$ e a menor pelo tangor da Índia $(2,49)$.

Segundo (Di Giorgi et al., 1990), as principais variedades comerciais para a industrialização do suco são : 'Hamlin', 'Pêra', 'Natal' e 'Valência'; elas apresentam indices tecnológicos que estāo entre 2,2 a 2,7. Das variedades de tangores e tangelos em estudo, todas estão adequadas quanto ao indice tecnológico, e apresentam valores que se situam entre 2,26 a 3,39, nos anos de 1996 e 1997. 


\subsubsection{Número de sementes}

A maior média para número de sementes, no primeiro ano, foi obtida pelo tangelo Minneola $(29,80)$, conforme observado na Tabela 3 e Figura 3. A menor média, nesse ano, foi obtida pelo tangor Santa Maria Madalena $(10,44)$. No segundo ano esse resultado foi confirmado apenas para a maior média, que continuou sendo do tangelo Minneola. Entretanto a menor média foi obtida pelo tangelo Seminole $(7,73)$.

Comparando os resultados obtidos com as variedades padrão tangor 'Murcott' e o tangelo Orlando, observa-se que o tangor da Índia, com média de 20,36 sementes e com intervalo de confiança de 18,34 a 22,38 e o tangor Ortanique com média de 21,96 sementes e intervalo de confiança entre 16,62 a 27,30, são considerados iguais ao tangor 'Murcott', que apresenta cerca de 20 sementes por fruto. Tal situação se repetiu no segundo ano. Todos esses valores, inclusive os do padrão, sāo muito elevados. O tangor Santa Maria Madalena, com média de 10,44 sementes é diferente do tangor 'Murcott' porque seus limites de confiança, com valores de 8,90 a 11,98 , não incluem a quantidade de sementes apresentada pelo tangor 'Murcott'. No segundo ano ocorreu o mesmo fato.

Com relaçāo aos tangelos, no primeiro ano, o tangelo Seminole, com média de 17,12 e intervalo de confiança de 13,50 a 20,74 sementes por fruto, é considerado igual ao tangelo Orlando que apresenta média de 15 sementes por fruto. No segundo ano, o tangelo Seminole, com média de 7,73 e intervalo de confiança 3,17 a 12,30 é considerado diferente ao tangelo Orlando, mas os valores estão próximos aos dele. Quanto aos tangelos Minneola e Sampson eles são considerados diferentes, pois seu número de sementes está bem acima do considerado para comparação. Valores menores que 10 e o mais próximo de zero, sāo bastante desejáveis.

A maioria das médias obtidas para número de sementes das variedades estudadas, são consideradas muito altas $\mathrm{e}$ inadequadas, principalmente para comercialização de frutas in natura. Comparando-se com as variedades principais comercializadas, elas também apresentam uma 
variação muito grande, pois, segundo (Figueiredo, 1991), as laranjas 'Bahia' e 'Baianinha' não apresentam sementes; as variedades de laranjas 'Pêra' e 'Natal' apresentam 3 a 4 sementes e o tangor 'Murcott' apresenta 20 sementes, por exemplo.

Quanto aos tangores e tangelos estudados, o tangor Santa Maria Madalena, com média de 10,44 e 12,57 e o tangelo Seminole com média de 17,12 e 7,73 sementes por fruto, nos dois anos de estudo, e o tangor da Índia, somente no segundo ano, com média 17,57 sementes, são considerados adequados em relaçāo aos padrōes. $O$ tangor Ortanique e os tangelos Minneola e Sampson são considerados inadequados quanto ao número de sementes por fruto, por possuírem mais que 20 sementes.

$\mathrm{O}$ alto número de sementes das variedades estudadas pode ter ocorrido devido um indice alto de fertilização cruzada, pois as variedades encontram-se no BAG-Citros, juntas com outras diversas variedades.

Uma visualizaçāo melhor da posição das variedades quanto à média e os intervalos de confiança para as variáveis rendimento de suco, indice tecnológico e número de sementes dos frutos, nos dois anos, pode ser verificada na Figura 3.

\subsubsection{Coloraçāo da polpa}

As variedades de tangelos Minneola, Sampson, Seminole e o tangor Ortanique, apresentam coloraçāo de suco alaranjada correspondendo ao código 4,4: 6,4: 1. As variedades de tangores da Índia e Santa Maria Madalena apresentam coloração de suco amarelo, pálido alaranjada correspondendo oa código 3: 5,5: 1,5, de acordo com (Biesalski, 1957).

Os tangelos Minneola, Sampson, Seminole e o tangor Ortanique tem a mesma coloração alaranjada das variedades comerciais laranja "Natal', Mexerica 'do Rio' e 'Ponkan' (Figueiredo, 1991). 

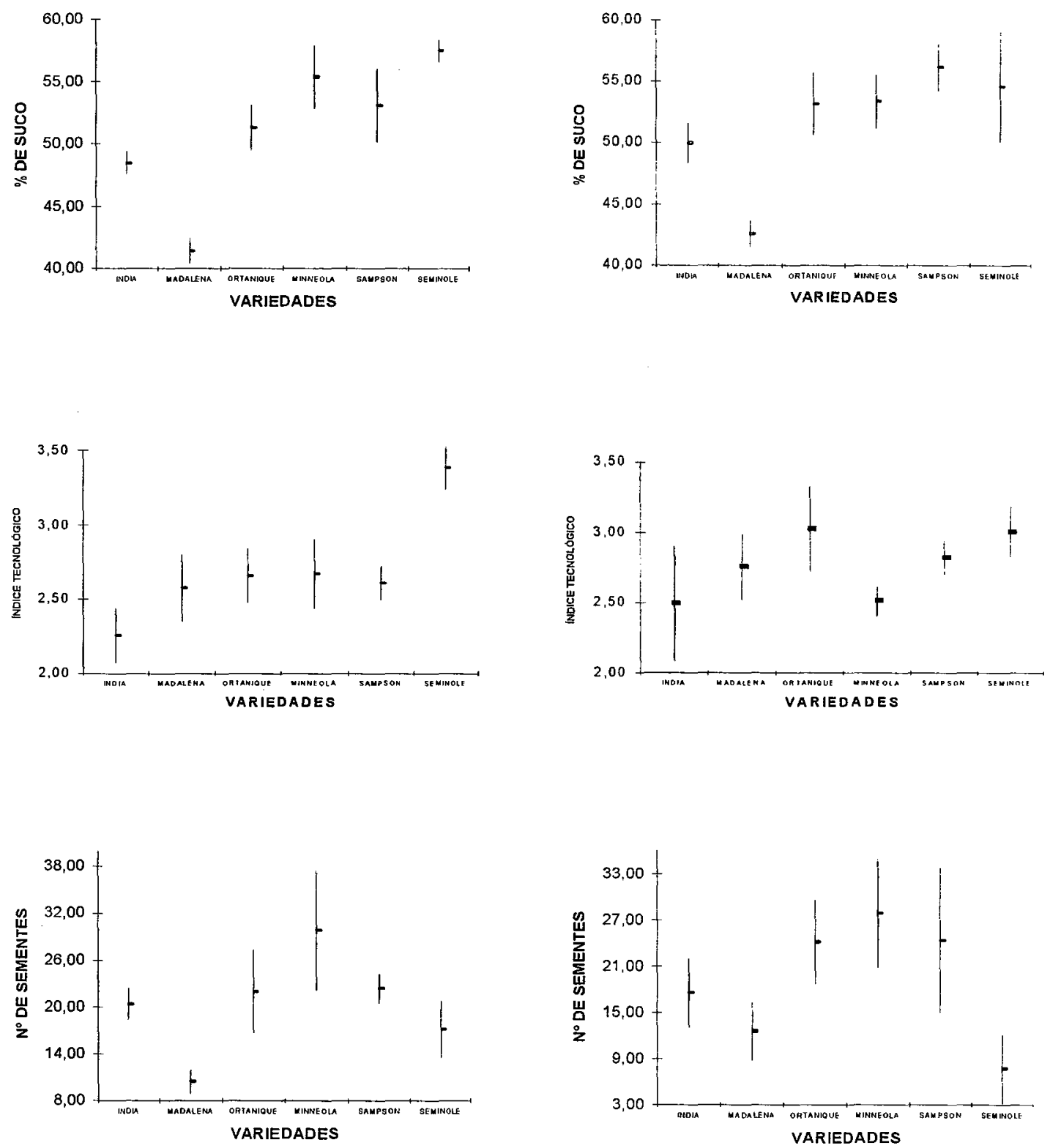

Ano (1996)

Ano 2 (1997)

Figura 3 - Médias e Intervalos de confiança (95\%) para as variáveis rendimento de suco, indice tecnológico e número de sementes, obtidos das variedades nos anos de 1996 e 1997. 


\subsection{Gráficos de raios de sol}

Pode-se ilustrar graficamente os resultados obtidos e discutidos acima, através dos gráficos sun ray plots, ou diagramas de raios de sol, que resumem o comportamento das variáveis medidas, para cada variedade em estudo.

Esse tipo de gráfico consiste em aplicar um fator de ponderação às médias de cada uma das variáveis estudadas (para transformá-las em uma medida comparável em grandeza) e colocar em cada eixo ou plotar as distancias (médias ponderadas) referentes a cada variável considerada. Para tal foram tomadas seis das variāveis estudadas, consideradas de maior importância para a industrialização dos frutos e para mercado de frutos in natura. As variáveis consideradas foram as seguintes: 


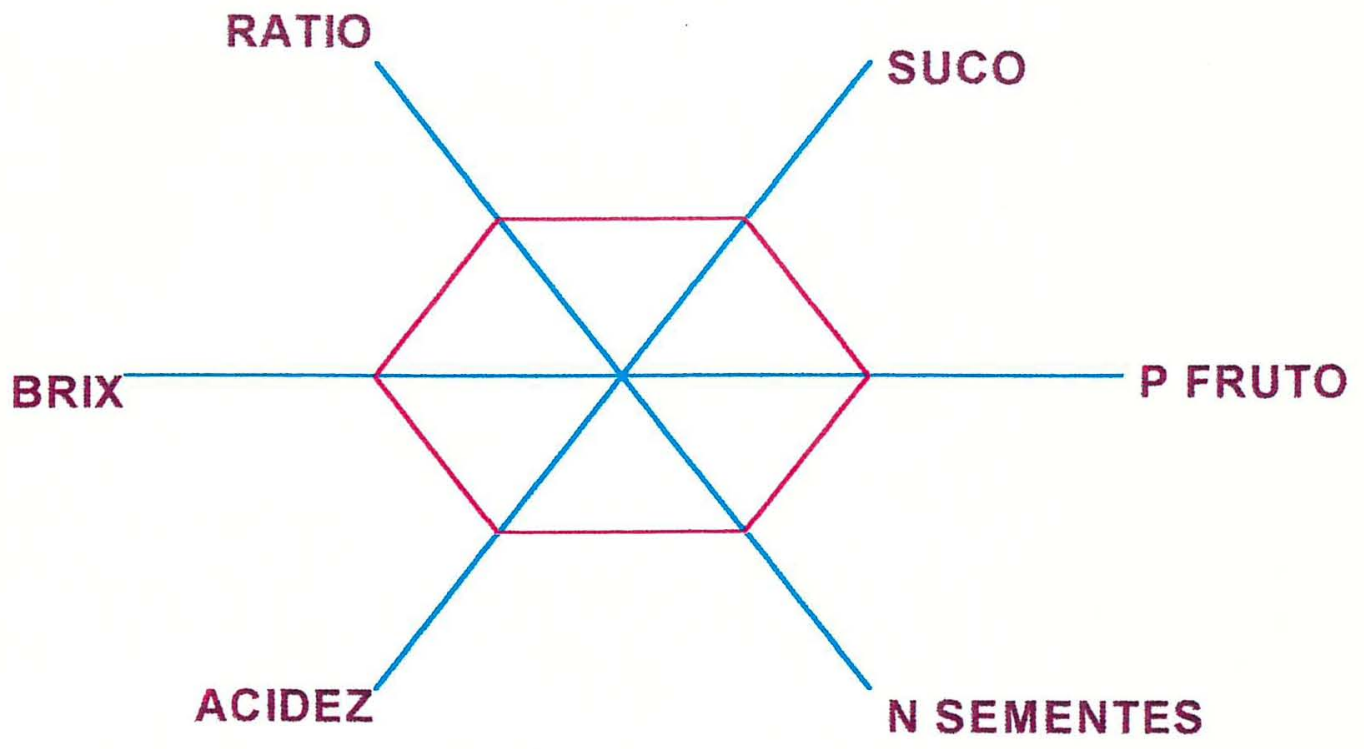


Os diagramas de raios de sol, referentes a cada uma das variedades de tangor analisadas e para a variedade padrão 'Murcott' com finalidade de comparação, são apresentados nas Figuras 4 e 5 , para o primeiro e segundo anos, respectivamente.

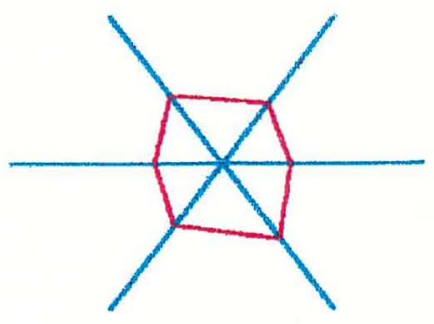

Tangor da India

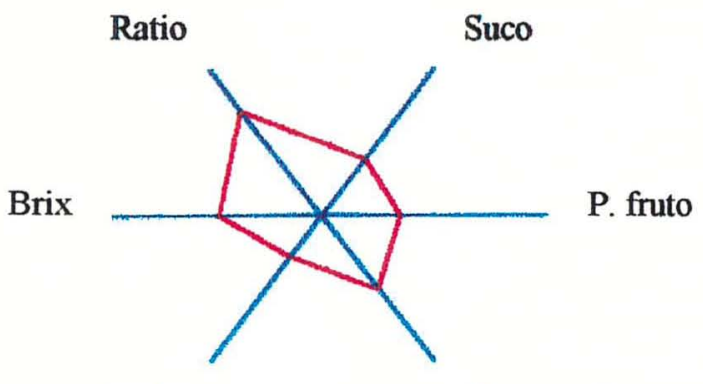

Acidez

N. sementes

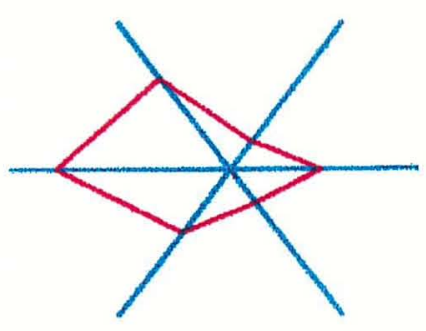

Tangor. S. M. Madalena

Tangor Murcott

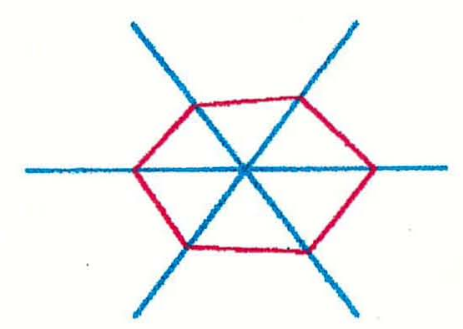

Tangor Ortanique

Figura 4 - Gráfico de raios de sol para a variedade padrão 'Murcott' e para os tangores da Índia, Santa Maria Madalena e Ortanique, com as variáveis: porcentagem de suco, peso do fruto, número de sementes, acidez, brix, e ratio, no ano de 1996 (primeiro ano). 


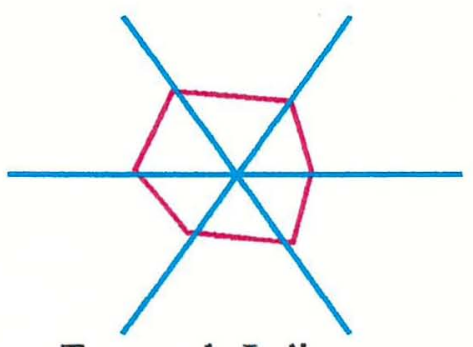

Tangor da India

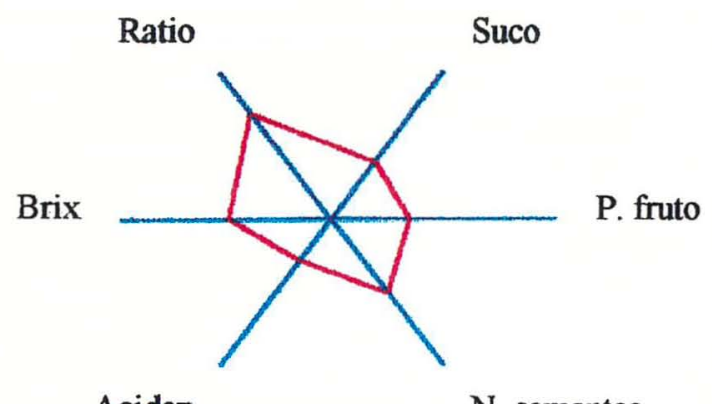
Acidez
N. sementes

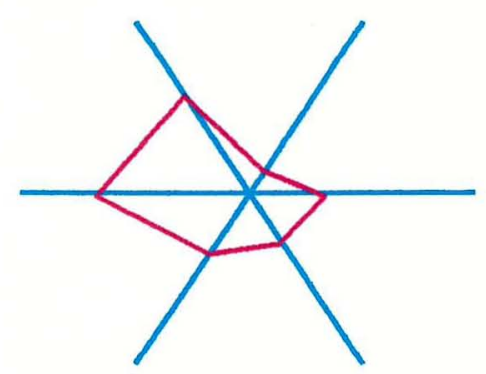

Tangor S. M. Madalena

Tangor Murcott

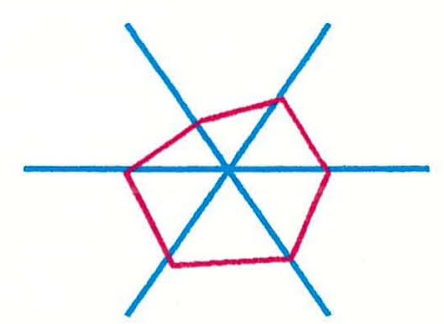

Tangor Ortanique

Figura 5 - Gráfico de raios de sol para a variedade padrão 'Murcott' e para os tangores da Índia, Santa Maria Madalena e Ortanique, com as variáveis: porcentagem de suco, peso do fruto, número de sementes, acidez, brix, e ratio, no ano de 1997 (segundo ano). 
Os diagramas de raio de sol referentes a cada uma das variedades de tangelo analisadas e para variedade padrão Orlando com finalidade de comparação, são apresentados nas figuras 6 e 7 respectivamente.

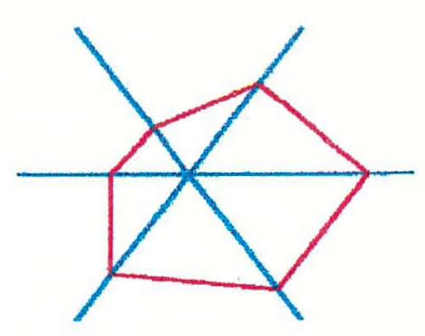

Tangelo Minneola

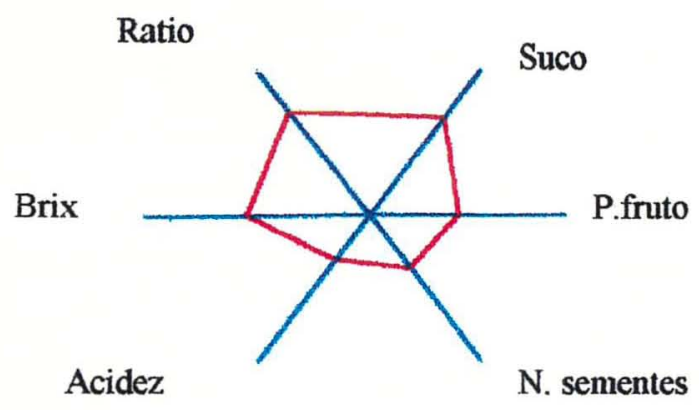

Tangelo Orlando

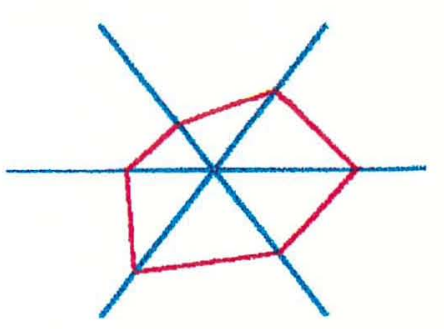

Tangelo Sampson

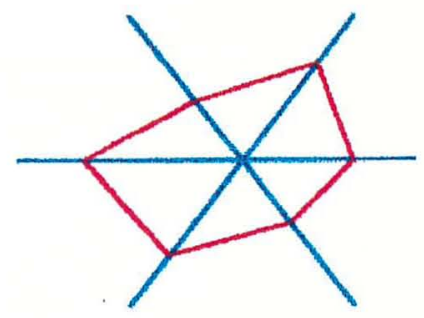

Tangelo Seminole

Figura 6 - Gráfico de raios de sol para a variedade padrão Orlando e para os tangelos Minneola, Sampson e Seminole, com as variáveis: porcentagem de suco, peso do fruto, número de sementes, acidez, brix, e ratio, no ano de 1996 (primeiro ano). 


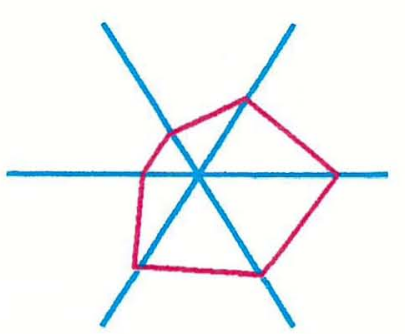

Tangelo Minneola
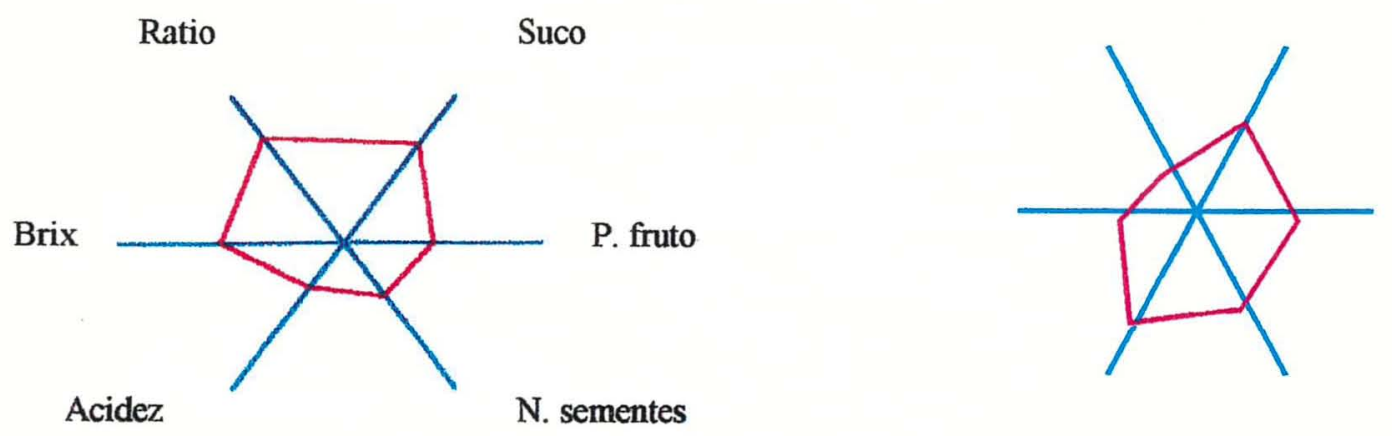

Tangelo Sampson

Tangelo Orlando

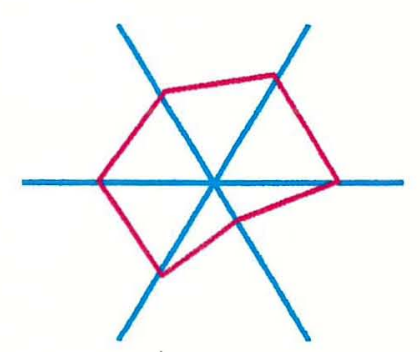

Tangelo Seminole

Figura 7 - Gráfico de raios de sol para a variedade padrão Orlando e para os tangelos Minneola, Sampson e Seminole, com as variáveis: porcentagem de suco, peso do fruto, número de sementes, acidez, brix e ratio, no ano de 1997 (segundo ano). 
Embora não possa ser utilizada a afirmação diferença significativa entre as variedades, uma vez que, devido a falta de delineamento experimental, não foi possivel aplicar um teste para fazer tal inferência, é permitido a partir da visualização dos sun ray plots, interpretar os resultados obtidos, como segue:

\subsubsection{Tangor da Índia}

Essa variedade apresentou melhor desempenho que os outros tangores em relação ao padrão, principalmente quando comparada através do diagrama de raios de sol.

Quanto ao peso do fruto, no primeiro e segundo anos $(133,28 \mathrm{e}$ $132,25 \mathrm{~g})$, os valores obtidos estão próximos aos da 'Murcott' (140 g) e o intervalo de confiança para o primeiro ano inclui o peso da mesma, podendo ser considerados iguais. O rendimento de suco no primeiro ano $(48,48 \%)$, é praticamente igual ao do padrão (48\%). No segundo ano o rendimento do suco foi maior $(49,95 \%)$ e diferente do da 'Murcott', isto porque o intervalo de confiança da variedade não cobre o da 'Murcott', o que é desejāvel, porque eleva o valor para próximo de $50 \%$. O brix da variedade no primeiro ano $(11,44 \%)$, é diferente do da 'Murcott' $(12,60 \%)$, pois o intervalo de confiança não atinge o do padrão. No segundo ano o brix $(12,20 \%)$ é considerado igual ao da 'Murcott', porque o intervalo de confiança da variedade abrange o da 'Murcott'. Entretanto o valor $11,44 \%$ é também aceitável. A acidez do tangor da Índia no primeiro e segundo anos $(1,24$ e 1,13\%), é diferente do da 'Murcott' $(0,92)$. O intervalo de confiança não atingiu o da 'Murcott'. O ratio da variedade no primeiro e segundo anos $(9,20$ e 10,93) é diferente do padrão $(13,70)$ e o intervalo de confiança não incluiu o da 'Murcott'. O número de sementes apresentado pela variedade no primeiro e segundo anos $(20,36$ e 17,57$)$ é considerado igual ao da 'Murcott' (20), pois o intervalo de confiança incluiu o da 'Murcott', fato que não é bom, pois deseja-se baixo número de sementes para uma fruta a ser comercializada in natura, por exemplo. 


\subsubsection{Tangor Santa Maria Madalena}

Esse tangor teve o pior desempenho entre os tangores estudados quando comparado ao padrão.

O peso do fruto dessa variedade também ficou próximo do da 'Murcott', somente no primeiro ano (149 g) e o intervalo de confiança (142,80 a $155,20 \mathrm{~g}$ ) abrangeu o peso do padrão. No segundo ano o peso dessa variedade foi superior ( $161,15 \mathrm{~g})$. Por esse tipo de avaliação é considerado diferente, porque o intervalo de confiança não incluiu o peso da 'Murcott'. Entretanto, dentro dessa faixa de peso, esse resultado é favorável, pois frutos mais pesados tendem a proporcionar maior lucro. Quanto ao rendimento de suco os resultados obtidos foram os piores entre os tangores, no primeiro e segundo anos $(41,42$ e 42,57\%) e diferente do padrão. O brix da variedade no primeiro e segundo anos $(15,02$ e 15,88\%), foi superior e diferente ao da 'Murcott' $(12,60 \%)$. A acidez obtida pela variedade no primeiro e segundo anos $(1,25 \mathrm{e}$ $1,19 \%)$ foi diferente do da 'Murcott' $(0,92 \%)$. O ratio da variedade foi maior entre os tangores no primeiro e segundo anos $(11,99$ e 13,57), mas somente no segundo ano foi considerado igual o da 'Murcott' $(13,70)$. Quanto ao número de sementes a variedade apresentou o menor número entre os tangores $(10,44)$ no primeiro ano e portanto diferente do da 'Murcott' (20). O mesmo ocorreu no segundo ano, o que é desejável.

\subsubsection{Tangor Ortanique}

O tangor Ortanique teve desempenho intermediário entre as variedades de tangores estudadas quando comparado com a 'Murcott'.

Foi a variedade que teve o maior peso entre os tangores no primeiro e segundo anos (174,10 e 184,05g), sendo diferente do da 'Murcott' $(140 \mathrm{~g})$. O intervalo de confiança não abrangeu o do padrão. Quanto ao 
rendimento de suco foi a variedade de que mais se destacou entre os tangores, no primeiro e segundo anos $(51,30$ e $53,17 \%)$ e foi diferente do da 'Murcott' (48\%). É uma característica desejável obter-se frutos com mais de $50 \%$ de suco. O brix da variedade no primeiro ano $(12,88 \%)$ esteve próximo ao da 'Murcott' $(12,60 \%)$ e foi considerado igual. No segundo ano o brix foi maior que o da 'Murcott' $(13,92 \%)$ e foi considerado diferente. Entretanto brix mais elevado, como o valor obtido, pode trazer lucros, uma vez que os frutos para a industrialização em São Paulo, já começam a ser pagos pelo brix que contém. A maior acidez entre os tangores ficou para essa variedade no primeiro e segundo anos ( 1,46 e 1,62\%). Foi diferente do da 'Murcott' ( 0,92\%). Esses valores foram considerados desfavoráveis. O ratio da variedade foi o pior entre os tangores, no primeiro e segundo anos $(8,89$ e 8,67) e diferente do da 'Murcott' $(13,70)$. O tangor Ortanique apresentou o maior número de sementes entre os tangores, no primeiro e segundo anos (21,96 e 24,17). Esse valor foi considerado igual o da 'Murcott' (20), porque o intervalo de confiança incluiu o da 'Murcott', nos dois anos. Conforme já mencionado, é desejado um baixo número de sementes para variedade copa.

\subsubsection{Tangelo Seminole}

A variedade apresentou o melhor desempenho entre os tangelos estudados em relação ao padrão tangelo Orlando.

O peso do fruto do tangelo Seminole $(162,06 \mathrm{~g})$, no primeiro ano foi maior que o do tangelo Orlando $(147 \mathrm{~g})$, mas foi considerado igual pois o intervalo de confiança incluiu o do Orlando. No segundo ano também foi maior $(209,62 \mathrm{~g})$ e diferente, porque o intervalo de confiança não incluiu o do Orlando. Realmente o segundo valor obtido é excessivo para a comercialização dos frutos. O rendimento de suco da variedade no primeiro e segundo anos $(57,48 \mathrm{e}$ $54,58 \%)$, foi considerado igual ao do Orlando $(57,33 \%)$. Quanto ao brix da variedade, no segundo ano (13,53\%), foi considerado igual ao do Orlando $(13,30 \%)$. No primeiro ano foi maior $(14,44)$ e pelo método utilizado foi 
considerado diferente. Entretanto são desejados maiores teores de açúcares para o caso da industrialização dos frutos. A acidez da variedade no primeiro e segundo anos $(1,73$ e $1,32 \%)$ foi diferente da do Orlando ( $0,97 \%)$. O ratio do Seminole, no primeiro e segundo anos ( 8,37 e 10,37), foi diferente do Orlando $(13,71)$. Os valores obtidos para ratio são considerados muito baixos, para a indústria. O número de sementes da variedade no primeiro ano $(17,12)$, è considerado igual ao do Orlando (15). No segundo ano, o número de sementes foi o menor entres os tangelos $(7,73)$ e diferente do Orlando. Seria muito adequado que esse valor baixo fosse mantido ao longo dos anos.

\subsubsection{Tangelo Sampson}

Essa variedade apresentou um desempenho intermediário entre o o tangelo Seminole e Minneola e em relação ao padrão.

O peso desse tangelo, no primeiro e segundo anos (182,78 e $215,40 \mathrm{~g})$ é bem superior e diferente do padrão $(147 \mathrm{~g})$. São valores considerados muito elevados para um tangelo com possivel valor comercial. Quanto ao rendimento de suco, no primeiro ano $(53,12 \%)$, foi diferente do obtido para o Orlando $(57,33 \%)$, devido os intervalos de confiança não abranger o do Orlando. No segundo ano, o rendimento de suco desse tangelo foi maior que no primeiro $(56,18 \%)$ e foi considerado igual ao Orlando. Esses altos valores obtidos são desejáveis. O brix do Sampson, no primeiro e segundo anos $(12,08$ e $12,30 \%)$ foi considerado diferente do padrão (13,30\%). A acidez também no primeiro e segundo anos $(1,86$ e $1,58 \%)$, foi superior entre os tangelos e diferente do Orlando $(0,97 \%)$. O ratio desse tangelo foi o menor entre todos no primeiro ano. Os valores para o primeiro ano $(6,49)$ e segundo ano $(7,84)$, foram diferentes do Orlando $(13,71)$. O número de sementes no primeiro e segundo anos $(22,40$ e 24,37$)$ foi considerado igual o obtido para Orlando (15), somente no segundo ano, porque o intervalo de confiança inclui o padrão. Valores esses que não são apropriados. 


\subsubsection{Tangelo Minneola}

O Minneola apresentou um pior desempenho entre os tangelos e ao padrão escolhido.

O peso do Minneola no primeiro e segundo anos $(207,32$ e 254,12 g) constitui-se na maior média entre os tangelos e foi diferente do obtido para Orlando (147 g). Quanto ao rendimento de suco, no primeiro e segundo anos $(55,38$ e 53,37\%), foi considerado igual ao do Orlando $(57,33 \%)$, somente no primeiro ano. Esses resultados, se mantidos, estão excelentes, para o caso da comercialização dos frutos. O brix da variedade no primeiro e segundo anos $(11,80$ e $11,55 \%)$, foi menor e diferente daquele do Orlando (13,30\%). A acidez, no primeiro e segundo anos $(1,84$ e 1,59\%), foi muito superior à do Orlando $(0,97 \%)$. O ratio no primeiro e segundo anos $(6,52$ e 7,33$)$ foi inferior e diferente do apresentado pelo Orlando $(13,71)$. O nümero de sementes obtido, no primeiro e segundo anos $(29,80$ e 27,87$)$ constituiu a maior média entre todos os tangelos e foi diferente do existente para o Orlando (15). Esse número é totalmente inadequado. 


\section{ConClusões}

A descrição das variedades e a discussão e interpretação dos resultados permitiram as seguintes conclusōes:

1. As variedades que apresentam maiores valores médios em tamanho de fruto foram os tangelos Sampson e Seminnole e o Minneola.

2. Os maiores valores médios para peso dos frutos foram obtidos com os tangelos Minneola e Sampson.

3. A maioria das variedades apresentou alto rendimento de suco, acima de $50 \%$, ficando os maiores valores para os tangelos Minneola, Sampson e Seminole e para o tangor Ortanique.

4. Todas as variedades apresentaram alto indice de sementes por fruto.

5. Os tangores e tangelos estudados, de uma maneira geral, não apresentaram resultados promissores para serem utilizado como copa, no periodo estudado. 


\section{REFERÊNCIAS BIBLIOGRÁFICAS}

BIESALSKI, E. Pflanzenfarben Atlas für Gartenbau, Landwirtschaft und Forstwesen mit Farbzeichan nach: DIN6164. Berlin, 1957, 1v.

CHITARRA, M.I.F.; CAMPOS, M.A.P. Caracterização de alguns frutos cítricos cultivados em Minas Gerais. IV Tangerinas Citrus reticulata Blanco em fase de maturação. In: CONGRESSO BRASILEIRO FRUTICULTURA, 6., Recife, 1981. Anais. Recife: SBF, 1981. v. 2, p.455-468.

DI GIORGI,F.; IDE, B.Y.; DIB,K.;MARCHI,R.J.; TRIBONI,H.de R.; WAGNER,R.L. Contribuição ao estudo do comportamento de algumas variedades de citros e suas implicaçōes agroindustriais. Laranja, v. 11, n. 2, p. 567-612,1990.

FIGUEIREDO, J.O. de. Variedades - copa de valor comercial. In: RODRIGUÉZ, O.; VIEGAS, F.; POMPEU JÚNIOR, J.; AMARO, A.A (Ed.). Citricultura brasileira. 2.ed. Campinas: Fundação Cargill, 1991. v. 1, p.228-264. 
GENÚ,P.J. de C.; PEDRAZZI,R.G.; STRINGHETA,P.C.; PINTO,A.C. de Q.; TEIXEIRA,M.A. Caracterização física da laranja 'Pêra '(Citrus sinensis L Osbeck) cultivada nos cerrados do Distrito Federal. In: CONGRESSO BRASILEIRO DE FRUTICULTURA, 6., Recife, 1981. Anais. Recife: SBF, 1981 , v.2, p. 469-480.

GIACOMETTI, D.C. Present status of citrus germplasm in Brazil. In: INTERNATIONAL CITRUS CONGRESS, Orlando, 1977. Proceedings. S.1.: International Society of Citriculture, 1977. v. 2, p.606-608.

GUARDIOLA,J.L. Frutificação e crescimento. In: SEMINÁRIO INTERNACIONAL DE CITROS, Bebedouro, 1992. Fisiologia. Campinas: Fundação Cargill 1992. p.1-26.

HODGSON, R.W. Horticultural varieties of citrus. In: REUTHER, W.; WEBBER,H.J. BATCHELOR, L.D. (Ed.) The citrus industry. Berkeley: University of California, 1967. v.1, p. 431-459.

INTERNATIOAL BOARD PLANT GENETIC RESOURCES. SECRETARIAT Descriptors for Citrus. Rome, 1988, 27p.

ORTOLANI, A. A. ; PEDRO JUNIOR, M. ; ALFONSI, R. R. Agroclimatologia e o cultivo dos citros. In: RODRIGUEZ, O.; VIÉGAS, F. ; POMPEU JUNIOR, J.; AMARO, A. A. (Ed.). Citricultura brasileira. 2 ed. Campinas: Fundação Cargill 1991. v. 1, p. 153-185. 
PIO, R.M. Caracterização e avaliação de frutos de oito variedades do grupo das tangerinas. Piracicaba, 1992. 77 p. Dissertação (Mestrado) - Escola Superior de Agricultura, "Luiz de Queiroz", Universidade de São Paulo.

PIO, R.M. Estudo de variedades do grupo das tangerinas: caracterização e avaliação dos frutos. Piracicaba, 1997. 89 p. Tese (Doutorado) - Escola Superior de Agricultura, "Luiz de Queiroz", Universidade de São Paulo.

POMPEU JÚNIOR, J. Porta-enxertos. In: RODRIGUÉZ, O., VIÉGAS, F.; POMPEU JÚNIOR, J.; AMARO, A.A. (Ed.). Citricultura brasileira. 2. ed. Campinas: Fundaçāo Cargill, 1991, v. 1, p.265-276.

SALIBE, A.A. Curso de especializaçăo em citricultura a nível de pósgraduado. 3. ed. Recife: SUDENE/UFRPE, 1974. 188p.

SAUNT, J. Variedades de citricos del mundo: guia ilustrado. Valência: Sinclair International, 1992. 128 p.

SILVA, M.M. da; SCRICH JÚNIOR, C.; POMPEU JÚNIOR, J.; BERETA, M.J.G.; ROSSETTI, V. ; DE NEGRI, J.D. de. Diversificação de porta-enxertos em viveiros de mudas cítricas como decorrência do Declínio dos citros no Estado de Sāo Paulo. Laranja, v.1, n. 11, p. 309 - 321, 1990.

TUBÉlIS,A. Presença da CVC em pomares paulistas. Coopercitrus Informativo Agropecuário, v. 8 n.90, p. 18-22, 1994. 
VIÉGAS, F. C.P. A industrialização dos produtos citricos. In: RODRIGUES,O.; VIÉGAS,F.; POMPEU JUNIOR,J.; AMARO,A.A. (Ed.). Citricultura brasileira. 2.ed. Campinas :Fundação Cargill, 1991. v.2, p.898-922. 
APÊNDICE 


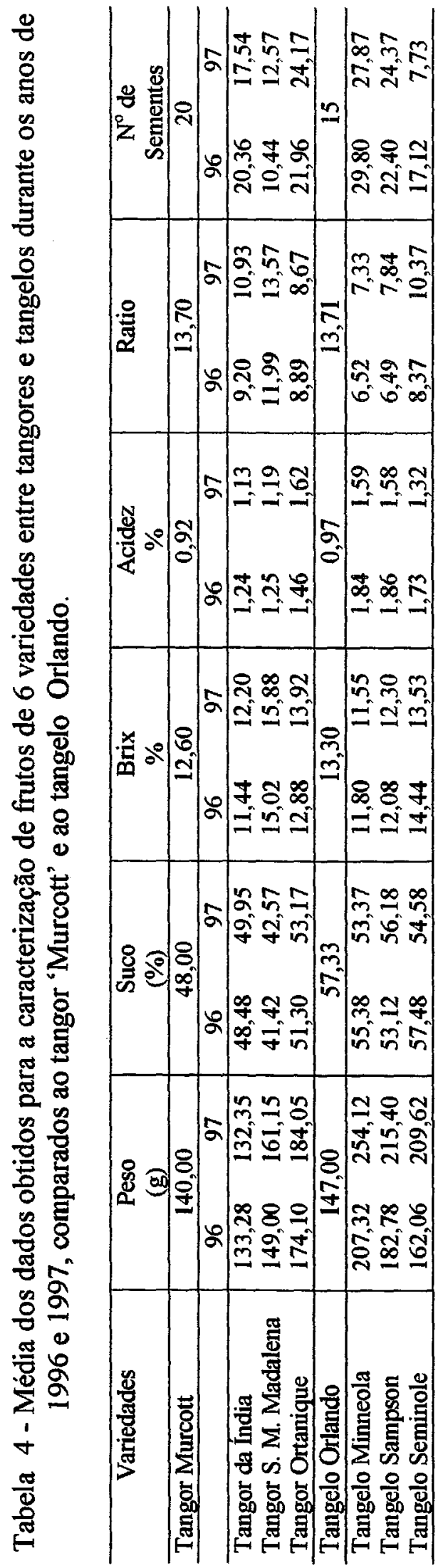




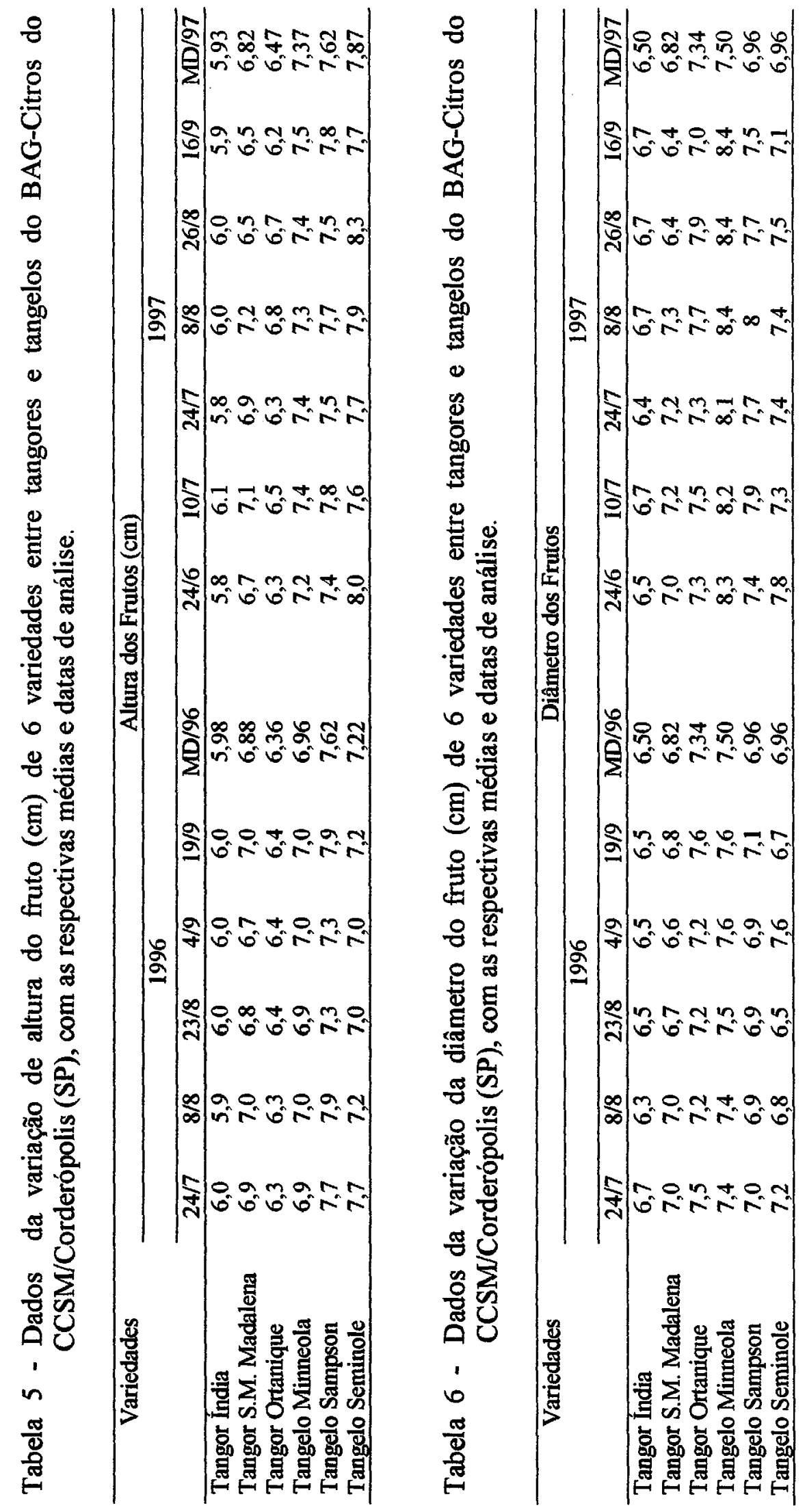




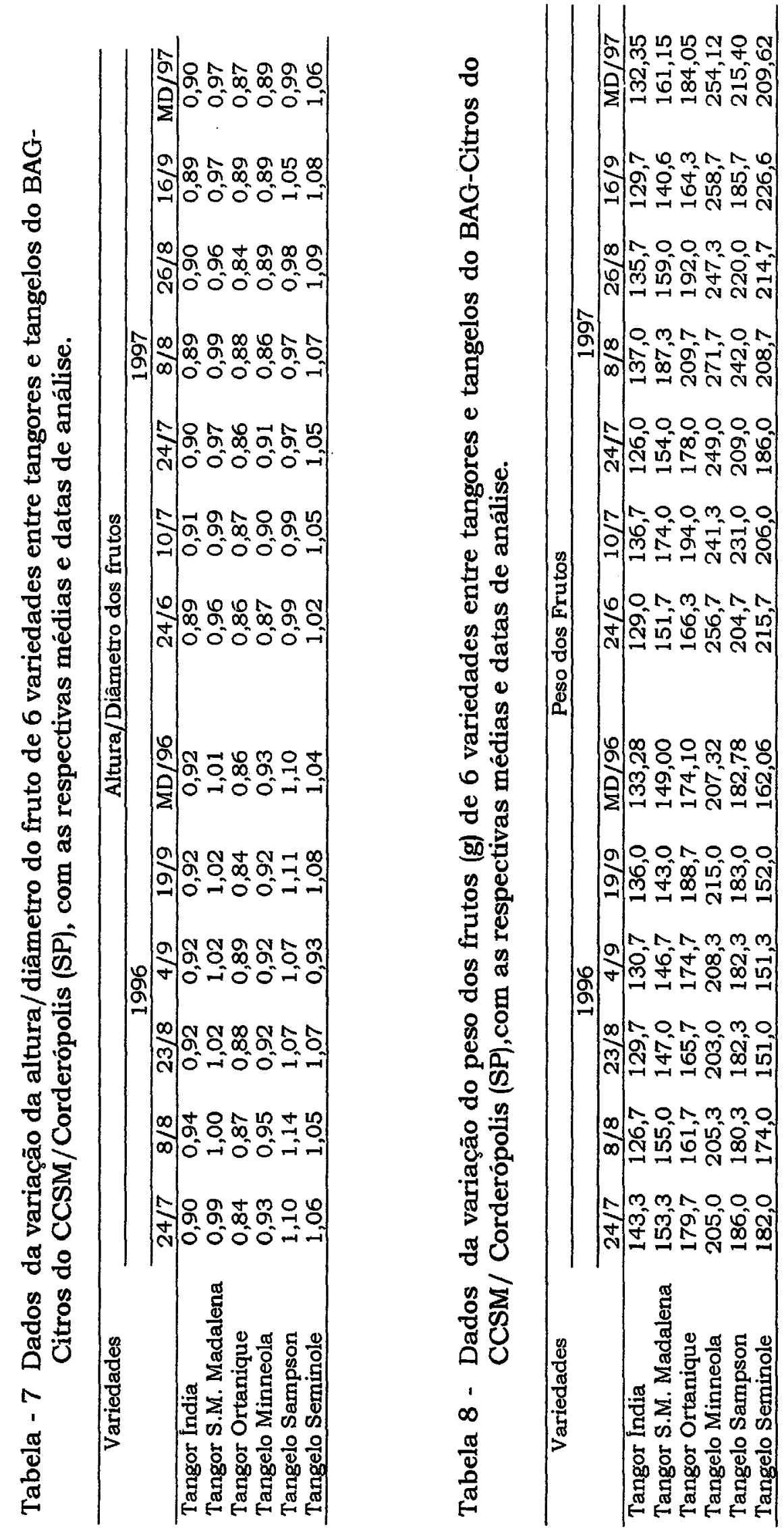




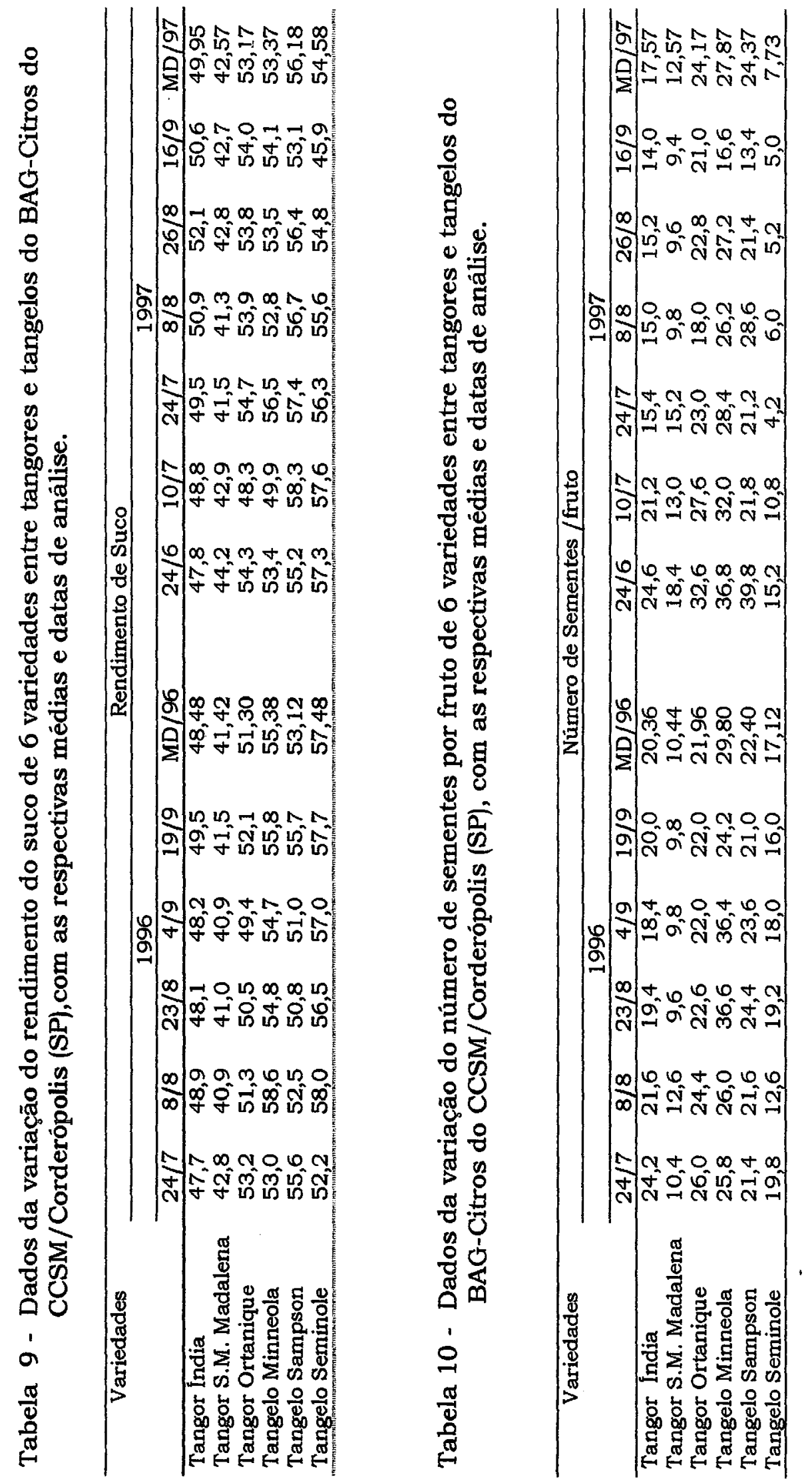




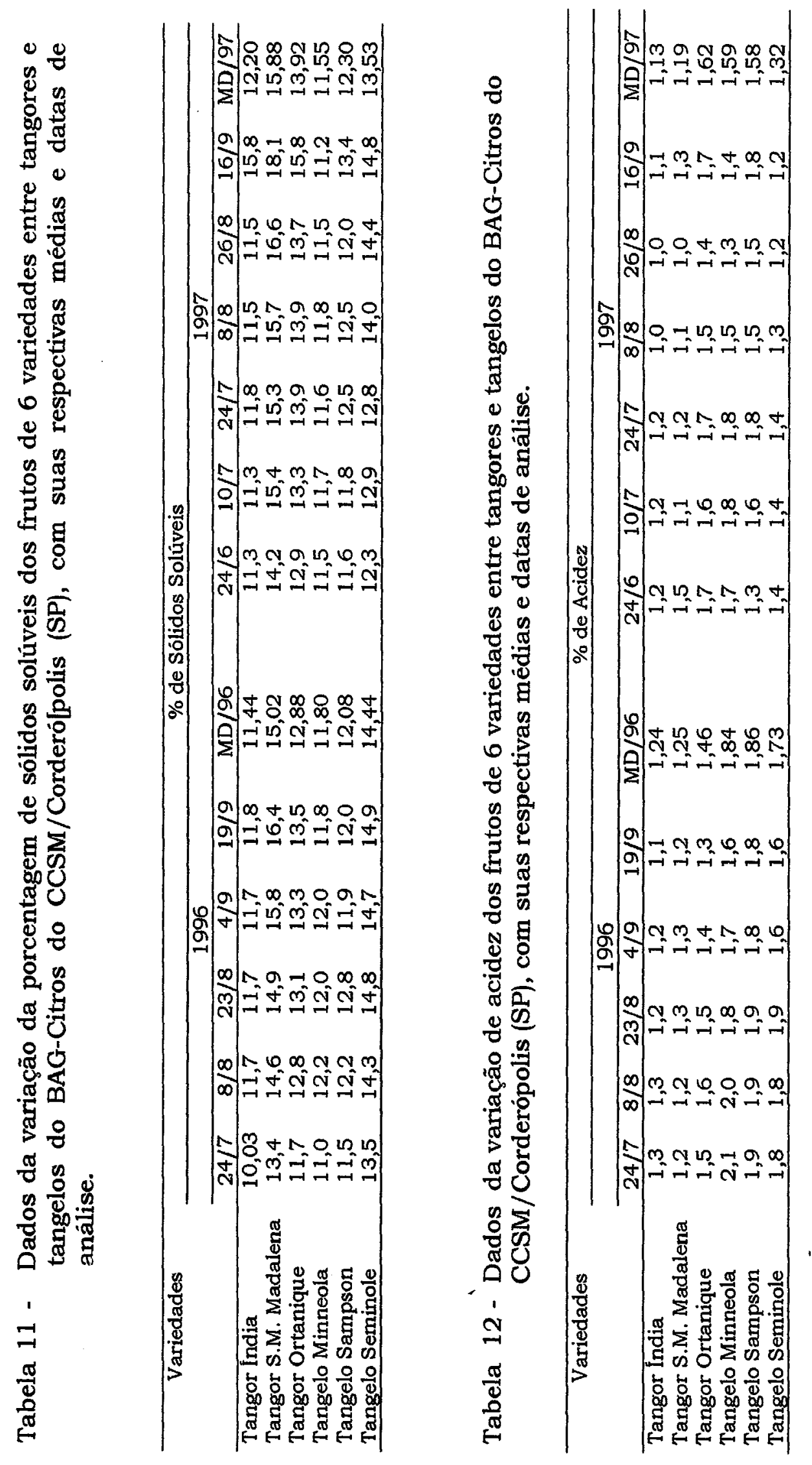



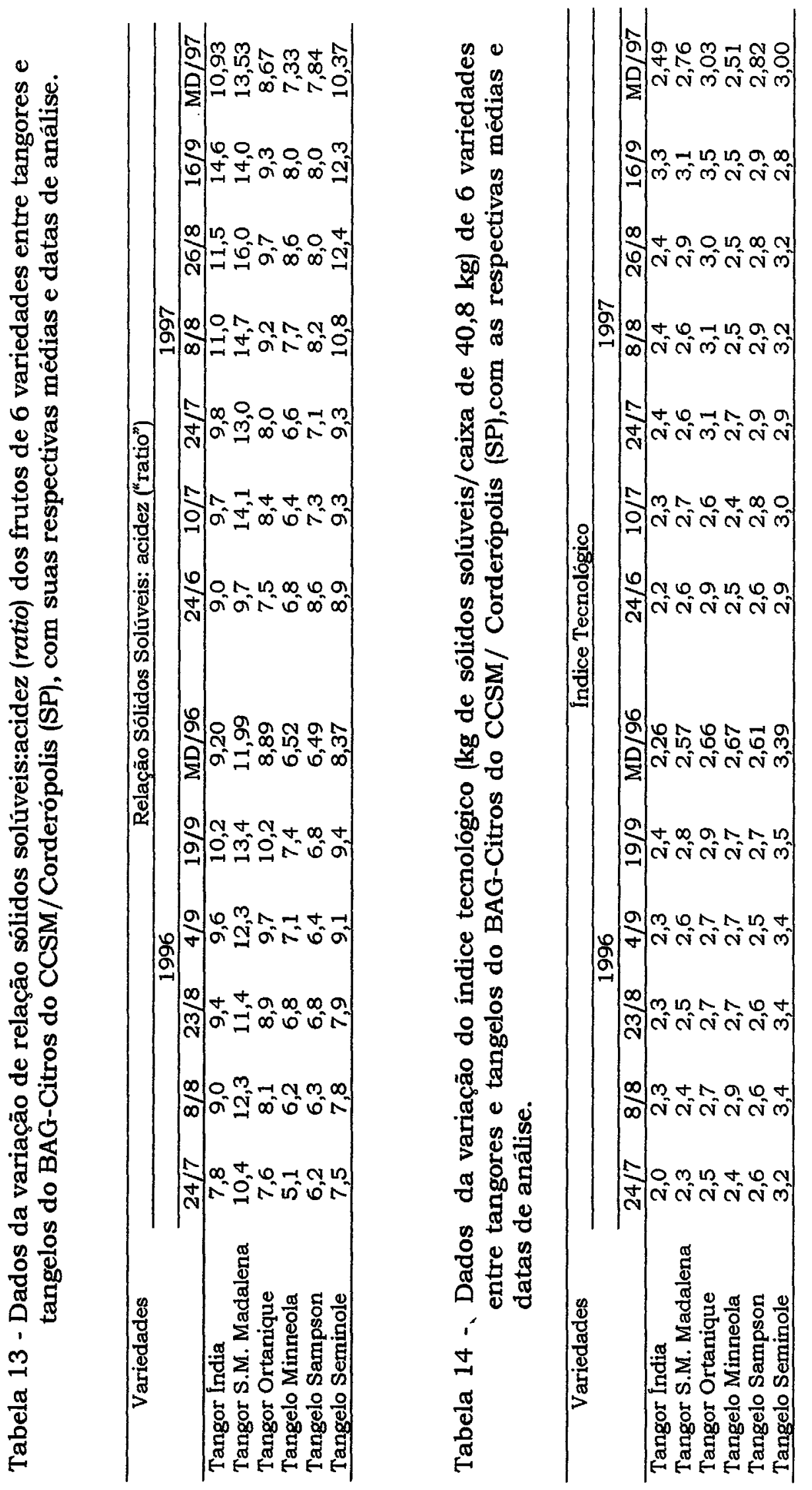


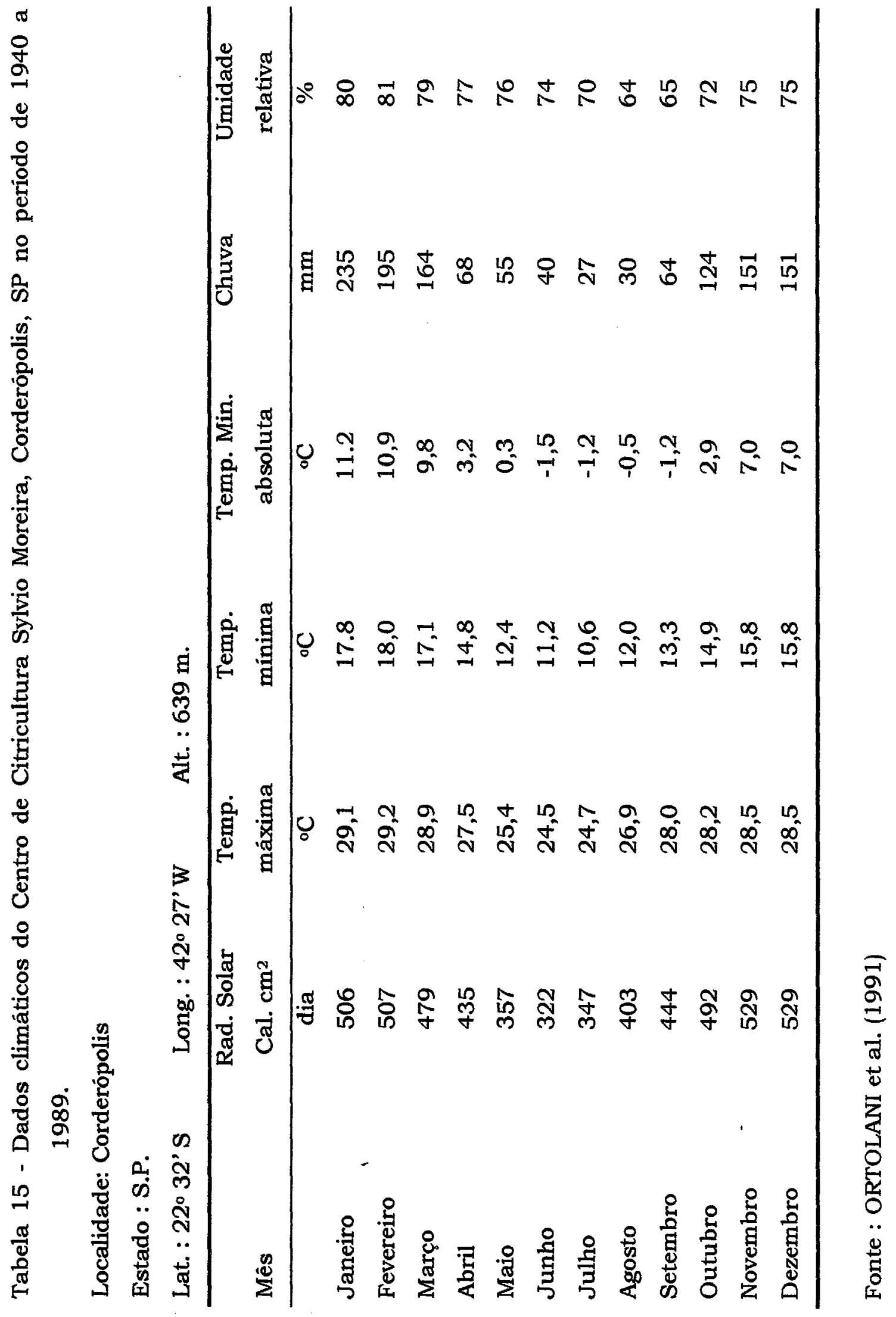




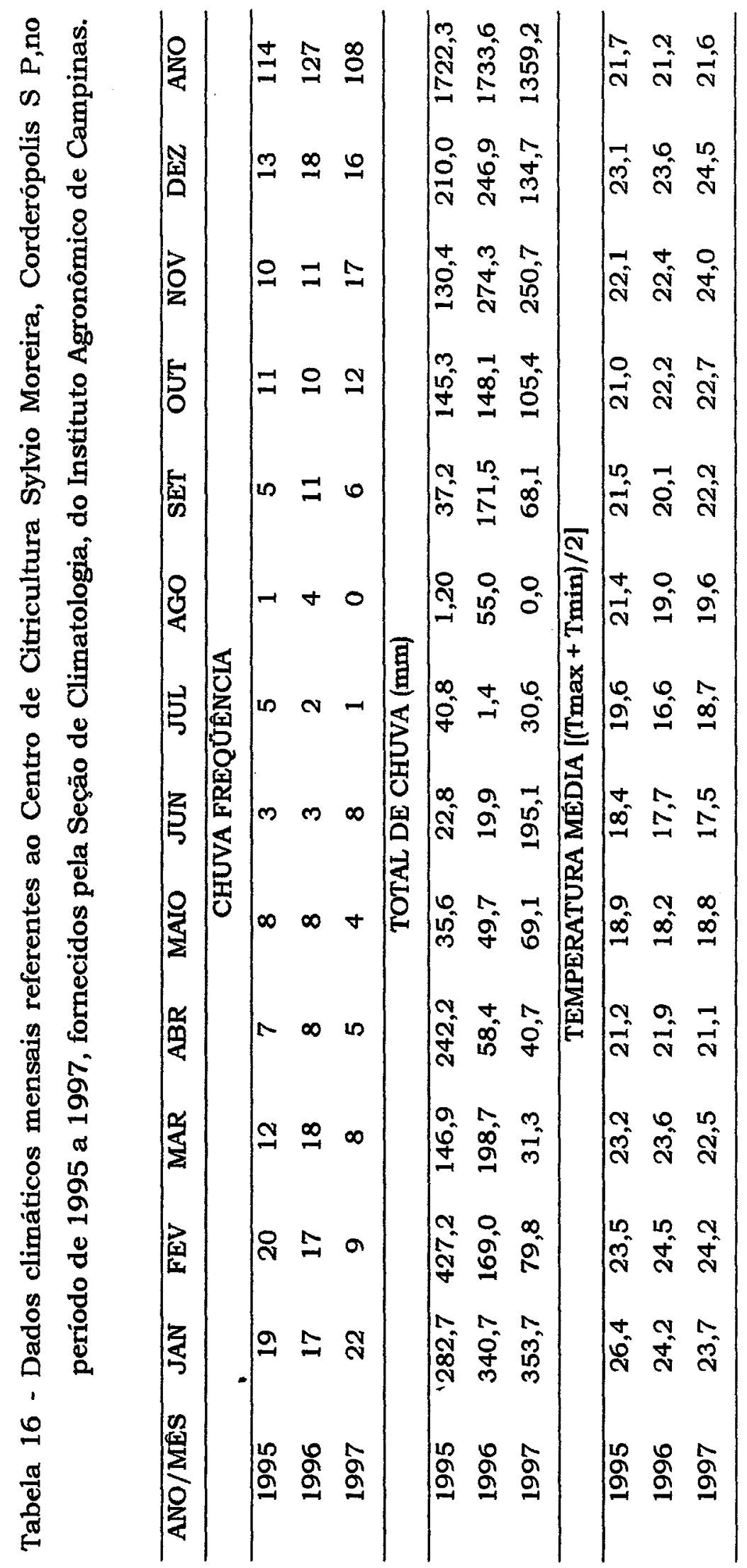

